Florida International University FIU Digital Commons

FCE LTER Journal Articles

FCE LTER

2011

\title{
Indirect and direct controls of macroinvertebrates and small fish by abiotic factors and trophic interactions in the Florida Everglades
}

\author{
Brooke L. Sargeant \\ Department of Biological Sciences and the Southeast Environmental Research Center, Florida International University \\ Evelyn E. Gaiser \\ Department of Biological Sciences and the Southeast Environmental Research Center, Florida International University, \\ gaisere@fiu.edu \\ Joel C. Trexler \\ Department of Biological Sciences and the Southeast Environmental Research Center, Florida International University, \\ trexlerj@fiu.edu
}

Follow this and additional works at: https://digitalcommons.fiu.edu/fce_lter_journal_articles

Part of the Life Sciences Commons

\section{Recommended Citation}

Sargeant, B., E.E. Gaiser, J.C. Trexler. 2011. Indirect and direct controls of macroinvertebrates and small fish by abiotic factors and trophic interactions in the Florida Everglades. Freshwater Biology 56(11): 2334-2346.

This material is based upon work supported by the National Science Foundation through the Florida Coastal Everglades Long-Term Ecological Research program under Cooperative Agreements \#DBI-0620409 and \#DEB-9910514. Any opinions, findings, conclusions, or recommendations expressed in the material are those of the author(s) and do not necessarily reflect the views of the National Science Foundation.

This work is brought to you for free and open access by the FCE LTER at FIU Digital Commons. It has been accepted for inclusion in FCE LTER Journal Articles by an authorized administrator of FIU Digital Commons. For more information, please contact dcc@fiu.edu, jkrefft@fiu.edu. 


\section{Freshwater Biology}

\section{Indirect and direct controls of macroinvertebrates and small fish by abiotic factors and trophic interactions in the Florida Everglades}

\begin{tabular}{|c|c|}
\hline Journal: & Freshwater Biology \\
\hline Manuscript ID: & FWB-P-Sep-10-0443.R2 \\
\hline Manuscript Type: & Standard Paper \\
\hline $\begin{array}{r}\text { Date Submitted by the } \\
\text { Author: }\end{array}$ & $n / a$ \\
\hline Complete List of Authors: & $\begin{array}{l}\text { Sargeant, Brooke; Florida International University, Department of } \\
\text { Biological Science } \\
\text { Gaiser, Evelyn; Florida International University, Department of } \\
\text { Biological Science } \\
\text { Trexler, Joel; Florida International University, Department of } \\
\text { Biological Science }\end{array}$ \\
\hline Keywords: & $\begin{array}{l}\text { Wetlands / mires / bogs / marshes < Habitat, Community < Level } \\
\text { of Organisation, Food webs < Process / Approach / Methods, } \\
\text { Trophic cascades < Process / Approach / Methods, Fish < } \\
\text { Taxonomic Group / Assemblage, Attached algae < Taxonomic } \\
\text { Group / Assemblage, Invertebrates < Taxonomic Group / } \\
\text { Assemblage }\end{array}$ \\
\hline
\end{tabular}

\section{SCHOLARONE \\ Manuscripts}



and trophic interactions in the Florida Everglades

11 Department of Biological Sciences and the Southeast Environmental Research Center

15 Corresponding author:

16 Joel C. Trexler

17 Department of Biological Sciences

18 Florida International University

1911200 SW 8th St.

20 Miami, FL 33199

21 Email: trexlerj@fiu.edu

22 Phone: 1-305-348-1966

23 Fax: 1-305-348-1986

25 Abbreviated title: Indirect and direct controls of Everglades consumers

26 Key words: indirect effects, bottom-up and top-down control, hydrological disturbance,

27 phosphorus, Florida Everglades 


\section{Summary}

30 1. The roles of nutrients, disturbance and predation in regulating consumer densities

31 have long been of interest, but their indirect effects have rarely been quantified in

32 wetland ecosystems. The Florida Everglades contains gradients of hydrological

33 disturbance (marsh drying) and nutrient enrichment (phosphorus), often correlated with

34 densities of macroinvertebrate infauna (macroinvertebrates inhabiting periphyton), small

35 fish and larger invertebrates, such as snails, grass shrimp, insects and crayfish. However,

36 most causal relationships have yet to be quantified.

37 2. We sampled periphyton (content and community structure) and consumer (small

38 omnivores, carnivores and herbivores, and infaunal macroinvertebrates inhabiting

39 periphyton) density at 28 sites spanning a range of hydrological and nutrient conditions

40 and compared our data to seven a priori structural equation models.

41 3. The best model included bottom-up and top-down effects among trophic groups and

42 supported top-down control of infauna by omnivores and predators that cascaded to

43 periphyton biomass. The next best model included bottom-up paths only and allowed

44 direct effects of periphyton on omnivore density. Both models suggested a positive

45 relationship between small herbivores and small omnivores, indicating that predation was

46 unable to limit herbivore numbers. Total effects of time following flooding were

47 negative for all three consumer groups even when both preferred models suggested

48 positive direct effects for some groups. Total effects of nutrient levels (phosphorus) were

49 positive for consumers and generally larger than those of hydrological disturbance, and

50 were mediated by changes in periphyton content. 
51 4. Our findings provide quantitative support for indirect effects of nutrient enrichment on

52 consumers, and the importance of both algal community structure and periphyton

53 biomass to Everglades food webs. Evidence for top-down control of infauna by

54 omnivores was noted, though without substantially greater support than a competing

55 bottom-up only model.

56

57

58

59

60

61

62

63

64

65

66

67

68

69

70

71

72

73 


\section{Introduction}

75 How abiotic and biotic factors influence populations and communities has long

76 been a central question in community ecology (e.g., Menge \& Sutherland, 1987; Pace et

77 al., 1999), but understanding their interactions and indirect effects as mediated by species

78 interactions remains a critical step to developing predictive models of how populations

79 are controlled and respond to environmental change (Wootton, Parker, \& Power, 1996;

80 Kneitel \& Chase, 2004; Gotelli \& Ellison, 2006). To identify the mechanisms by which

81 environmental gradients influence communities, they must be examined in the context of

82 food webs and using methods that can explore their interactions and community-level

83 effects. We used structural equation modeling, a multivariate technique that explicitly

84 examines indirect and direct effects, to determine how hydrological disturbance, nutrients

85 and trophic interactions influence primary production and densities of small consumers

86 (predominantly invertebrates and small fish) in the Florida Everglades.

87 Studies of aquatic systems have revealed diverse effects of disturbance,

88 productivity and predation on food webs, densities and community structure (e.g., Power,

89 Parker, \& Wootton, 1996; Shurin et al., 2002; Chase, 2003). In pond and wetland

90 ecosystems, hydrological disturbance is expected to shape community structure by

91 permanently limiting or periodically reducing biota, especially larger organisms

92 (Wellborn, Skelly, \& Werner, 1996). Disturbance in the form of drought can decrease

93 macroinvertebrate and fish densities through direct mortality or reduction of food

94 biomass. In habitats where larger organisms are more susceptible to drying conditions,

95 droughts may actually increase macroinvertebrate densities by removing predatory fish

96 (Corti, Kohler, \& Sparks, 1997; Liston, 2006; Dorn, 2008). The effects of nutrient 
97 enrichment on fish and invertebrate densities can depend on disturbance, the strength of

98 trophic interactions, and the degree to which predators can reduce prey populations. For

99 example, while fish biomass generally increases with nutrients, similar increases in

100 invertebrate biomass may hinge on whether fish are present and limit invertebrate

101 densities (Wootton \& Power, 1993; Marks, Power, \& Parker, 2000; Liston, 2006).

102 Increasing nutrients can also encourage successional changes toward well-defended but

103 competitively inferior invertebrates and thereby reduce the strength of trophic cascades

104 by fish (Chase, 2003). Relatively few studies have addressed these interactive effects and

105 indirect relationships in wetlands, leaving such questions unanswered for many systems.

106 The Florida Everglades is a highly oligotrophic marsh ecosystem with gradients

107 of anthropogenic nutrient (phosphorus) enrichment and hydrological disturbance (drying

108 of the marsh) (Gunderson \& Loftus, 1993; Davis, 1994). Drying events cause direct

109 mortality of fish and invertebrates as well as movements toward deeper refuges, and thus

110 community trajectories in the Everglades reveal shifts from abiotic to biotic control as a

111 function of time following a disturbance (Trexler, Loftus, \& Perry, 2005), similar to

112 patterns in floodplain habitats (Winemiller, 1996). The density of small fish typically

113 increases with time following a drying event (Trexler et al., 2002, 2005; Dorn, 2008) and

114 often with nutrient levels (Turner et al., 1999; Trexler et al., 2002; Gaiser et al., 2005).

115 Similarly, invertebrates often increase coincident with hydroperiod and nutrients,

116 although this pattern varies with taxa, sampling method, microhabitat and nutrient level

117 (Rader \& Richardson, 1994; McCormick, Shuford, \& Rawlik, 2004; Liston, 2006; King

118 \& Richardson, 2007; Liston, Newman, \& Trexler, 2008). It is generally presumed that

119 nutrients amplify fish and macroinvertebrate densities indirectly via stimulation of 
120 periphyton production (aggregations of benthic algae, detritus, fungi and bacteria), a

121 major source of primary production for the food web and habitat for invertebrates.

122 Nutrient enrichment, localized around areas of water inflow, alters algal community

123 composition and consequently changes the periphyton physical structure and constitution

124 (e.g., from floating calcareous mats to epiphytic filamentous green algae aggregates)

125 (McCormick et al., 1996; Gaiser et al., 2005, 2006). Hydrology may also shape

126 periphyton community structure (Gottlieb, Richards, \& Gaiser, 2006; Thomas et al.,

127 2006). The maintenance of large expanses of periphyton and apparent limits on

128 macroinvertebrate densities suggest that fish predation on invertebrates may generate a

129 trophic cascade (Turner et al., 1999; Liston, 2006).

130 While these general trends in Everglades communities have been identified,

131 indirect and direct effects and food-web interactions have not yet been explicitly

132 quantified in natural contexts and at large spatial scales. Anthropogenic activities have

133 modified the Everglades through nutrient enrichment and alteration of hydrological

134 patterns (Davis, 1994), and the Everglades is now the subject of a large-scale restoration

135 project (Davis \& Ogden, 1994). Using structural equation modeling (path analysis) and a

136 model comparison approach, we identified possible causal models quantifying the

137 indirect, direct and total effects of drought, nutrient enrichment and trophic interactions

138 on small aquatic consumers in the Everglades. This analysis provides greater insight into

139 possible mechanistic models describing how basal consumer densities are controlled in

140 this ecosystem, informing restoration policies and practices.

141

142 


\section{Methods}

\section{Field Sampling and Sample Processing}

145 In November and December 2005, we sampled fish, amphibian and aquatic invertebrate 146 communities in 28 sites across the Florida Everglades (Everglades National Park, Water

147 Conservation Areas, and Loxahatchee National Refuge; approximately $25^{\circ} 19^{\prime} \mathrm{N}$,

$\left.14880^{\circ} 56^{\prime} \mathrm{W}\right)$ (Fig. 1). Sampling sites were selected from a larger set of possible study sites

149 identified by a Generalized Random Tessellation Stratified (GRTS) survey design

150 (Stevens and Olsen 2003) applied to the Greater Everglades ecosystem (Scheidt and

151 Kalla 2007). The GRTS design provides a specially balanced sample of the ecosystem;

152 sites were selected for this study because they were located in wet-prairie slough habitats

153 that are the focus of management concern because of their role as foraging habitats for

154 wading birds (Trexler and Goss 2009); wet prairie sloughs are characterized by

155 spikerush-dominated (Eleocharis cellulosa Torr.) emergent vascular plants (Gunderson

1561994 ) and large standing stocks of periphyton mats formed by benthic algae, detritus,

157 fungi and bacteria (Turner et al. 1999). Sargeant et al. (2010) and Table 1 provide further

158 description of the conditions at these sites.

159 We sampled small fish and amphibians $(<8 \mathrm{~cm})$ and large invertebrates (snails,

160 crayfish, grass shrimp, and large insects, $>5 \mathrm{~mm}$ ) using a standardized throw-trap

161 sampling protocol (Jordan, Coyne, \& Trexler, 1997) with 1-m² throw traps enclosed by 2-

$162 \mathrm{~mm}$ mesh. Traps were cleared using a bar seine (2-mm mesh) and dip nets (1- and 5-mm

163 mesh), and vertebrates were euthanized by immersion in an MS-222 (tricaine

164 methanesulfonate) bath. Three throw-trap samples were collected per site. To sample

165 macroinvertebrate infauna (including nematodes, copepods, and cladocerans, inhabiting 
166 periphyton mats, typically $0.25-8 \mathrm{~mm}$ long), periphyton mat samples (6-cm diameter

167 cores from top to bottom of the mats, typically $2.5 \mathrm{~cm}$ deep) were collected from within

168 each throw trap (Liston and Trexler 2005). All animals captured were kept on ice in the

169 field, and then frozen for storage before identification and enumeration in the lab. The

170 densities (number $\cdot \mathrm{m}^{-2}$ ) of small primary and secondary consumers were determined for

171 each site by calculating the mean of the counts from the three throw-trap samples.

172 Herbivores included herbivorous fish, tadpoles, beetles, mayfly larvae and snails. Small

173 fish, newts, sirens, beetle larvae, odonate larvae, insects, crayfish and shrimp were

174 considered secondary consumers and are omnivorous or carnivorous in the Everglades.

175 Periphyton subsamples $(15-30 \mathrm{~mL})$ were haphazardly selected from thawed cores and

176 two different workers identified macroinvertebrates under a light microscope. Periphyton

177 macroinvertebrate density (number $\cdot \mathrm{m}^{-2}$ ) (Liston, 2006) was determined for each site

178 using the means of the three periphyton core samples. Details on species collected, their

179 densities and frequency of occurrence at sites, and their trophic classification (for throw-

180 trap organisms) are available in Table S1 of Supporting Information Appendix S1. All

181 trophic assignments were based on published and unpublished studies reporting gut

182 content (Gunderson and Loftus, 1993; Loftus 1999), stable isotopic (Loftus 1999;

183 Williams and Trexler 2006; Sargeant et al. 2010) and fatty acid profile (LL Belicka,

184 personal communication) analyses of specimens collected from the Everglades. Feeding

185 relationships of Everglades aquatic animals are complex, with widespread omnivory and

186 intraguild predation; a small fraction of animals sampled for this study are exclusively

187 carnivores (e.g., dragonfly naiads) feeding on other omnivores and herbivores. For

188 simplicity sake, we have lumped these animals as 'omnivores' for this study, consistent 
189 with Morin's (1999) definition that omnivores are species that feed at more than one

190 trophic level.

191 We determined phosphorus levels, periphyton composition and hydrological

192 disturbance estimates corresponding to each of our sites. Periphyton volume (ml) was

193 estimated in the field by placing periphyton in graduated cylinders, and periphyton aerial

194 cover (\%) was measured as the estimated percentage of the surface area enclosed by the

195 throw trap that was covered by periphyton. Separate periphyton samples (3 samples per

196 site, corresponding to locations of throw-trap samples) were obtained to determine total

197 phosphorus content (TP) $\left(\mu \mathrm{g} \cdot \mathrm{g}\right.$ dry $\left.{ }^{-1}\right)$, ash-free dry mass $($ AFDM $)\left(\mathrm{g} \cdot \mathrm{m}^{-2}\right)$ as an estimate

198 of biomass, percent nitrogen and organic content, chlorophyll $a$ concentration $\left(\mu \mathrm{g} \cdot \mathrm{g} \mathrm{dry}^{-1}\right)$

199 and density $\left(\mu \mathrm{g} \cdot \mathrm{m}^{-2}\right)$ and algal species composition as described by Gaiser et al. (2006;

200 see also Stevenson et al. 2002). Total phosphorus from periphyton is a valuable indicator

201 of nutrient enrichment because phosphorus is quickly absorbed by biota and does not

202 remain in the water column (Gaiser et al., 2006). Algal species were categorized as green

203 algae, diatoms, non-filamentous bluegreen algae (cyanobacteria), filamentous blugreen

204 algae, and the combined relative abundance of diatoms and green algae was used in

205 analyses because those species are thought to be more palatable to consumers (Geddes \&

206 Trexler, 2003). Using the Everglades Depth Estimation Network (EDEN) hydrological

207 estimation tool (http://sofia.usgs.gov/eden/stationlist.php), we calculated time since

208 flooding as the number of days since flooding after the most recent drying event (water

209 levels $<5 \mathrm{~cm}$ ). Using this as a measure of time to recover following a drought,

210 hydrological disturbance is inversely related to time since flooding. Sampling occurred 
211 in the late wet season when marshes were near peak water depths following summer

212 rains.

213

214 Data Analysis

215 To examine complex interactions between these variables in a food-web context,

216 we used structural equation modeling to identify relationships between TP levels, time

217 since flooding, periphyton AFDM, the relative abundance of green algae and diatoms, the

218 density of periphyton macroinvertebrate infauna and the densities of small consumers

219 (fish and large invertebrates from throw-trap samples). Structural equation modeling

220 enables analysis of systems involving multiple simultaneous cause-effect relationships, in

221 contrast to reductionist approaches that examine these relationships singly, with the

222 potential to improve understanding of interaction networks typical of ecological

223 communities (Grace, 2006). For example, it can be used to identify species interactions

224 and their direct, indirect and total effects (Johnson, Huggins, \& DeNoyelles, 1991;

225 Wootton, 1994a,b). This method can be applied to experiments (e.g., Johnson et al.,

226 1991; Wootton, 1994a,b) or observational data recorded along gradients of natural

227 variability (e.g., Elmhagen \& Rushton, 2007; Riginos \& Grace, 2008).

$228 \quad$ We developed seven a priori models describing hypothesized causal mechanisms

229 for how disturbance, productivity and trophic interactions may determine the densities of

230 small consumers via direct and indirect pathways, based on results of previous studies

231 and theoretical expectations (see Supporting Information Appendix S2 for detailed

232 descriptions of each model and rationale). Models were based on bottom-up control only

233 or reciprocal relationships (both bottom-up and top-down controls) between consumers 
234 and prey. Specifically, top-down control was proposed between 1) omnivores and

235 infauna, 2) infauna and periphyton biomass, 3) herbivores and periphyton biomass, and

236 4) omnivores and periphyton biomass. The relationship between herbivores and

237 omnivores was evaluated by comparing models that contained a causal path from

238 herbivores to omnivores to models that assumed no causal link between them. We were

239 unable to include a possible top-down relationship between omnivore density and

240 herbivore density due to empirical underidentification. A model is considered identified

241 if unique estimates can be determined for all of its parameters, which requires a sufficient

242 number of observed variables given the number of parameters to solve (Grace, 2006). In

243 some cases, a model can be theoretically identified but empirically underidentified

244 because of correlations inherent in the data that effectively reduce the number of

245 observations (Kline, 2005; Grace, 2006). However, the small omnivores in question may

246 be unlikely to limit herbivores of similar size.

247 Structural equation modeling (path analysis) was conducted using AMOS 7.0

248 (Amos Development Corporation, Spring House, PA, USA). The site was considered the

249 unit of observation ( $\mathrm{n}=28)$, with the periphyton, hydrological and consumer variables

250 calculated for each site. All variables were $\log _{10}(y+1)$ transformed to improve

251 univariate normality and reduce nonlinearities in relationships. Despite transformations,

252 the data continued to show signs of deviation from normality (as indicated by univariate

253 analyses, Mardia's coefficient for multivariate kurtosis, and Mahalanobis $d$ ), so we used

254 bootstrapping (based on 2000 bootstrap samples) to test absolute model fit using the

255 Bollen-Stine chi-square test. When data are highly non-normal, traditional chi-square

256 tests of model fit can be overly conservative and the Bollen-Stine chi-square test, which 
257 uses bootstrapping to determine the probability of model fit, is recommended as an

258 alternative (Byrne, 2000; Grace, 2006). Models were compared using the Bayesian

259 Information Criterion (BIC) (lower BIC values indicate better fit), which weighs

260 improvement in model fit against model complexity (Claeskens \& Hjort, 2008). We

261 report BIC instead of the more common Akaike's Information Criterion (AIC) because

262 BIC provides more consistent model selection as model complexity increases; BIC

263 applies a higher penalty than AIC for adding parameters (Claeskens \& Hjort, 2008:

264 Chapter 4) and is more conservative than AIC in the presence of model uncertainty

265 (Burnham and Anderson 2010: pp 271-273). Because we used a model-comparison

266 approach, path coefficients are presented, but were not tested for statistical significance

267 (e.g., Gotelli \& Ellison, 2006). We present the unstandardized and standardized path

268 coefficients fitted by maximum likelihood for each direct causal path in the final models.

269 Path coefficients in the model represent partial regression coefficients. Reported total

270 effects of environmental gradients are the sum of direct and indirect causal paths. Our

271 approach should be viewed as exploratory and hypothesis-generating rather than

272 confirmatory given our limited trophic specification made necessary by high sample-size

273 requirements of our model fitting and comparison approach.

274

275 Results

276 Samples contained many of the small aquatic fauna common to the Everglades

277 (see Table S1 of Supporting Information Appendix S1). Throw-trap samples were

278 dominated by small fish, grass shrimp, crayfish and dragonfly larvae. Of these, grass

279 shrimp (Palaemonetes paludosus, Gibbes) had the largest mean density across all the 
280 sites of the omnivorous species and was present in more than $70 \%$ of the sites. Least

281 killifish (Heterandria formosa, Girard), mosquitofish (Gambusia holbrooki, Girard) and

282 bluefin killifish (Lucania goodei, Jordan) were also very common and thus typically

283 contributed notably to omnivore density. Herbivorous fish and large invertebrates were

284 lower in density, dominated by planorbid snails (Planorbella spp.) with the highest mean

285 density, and flagfish (Jordanella floridae, Goode and Bean) at the largest number of sites.

286 Cladocerans, nematodes, copepods, water mites, ostracods, amphipods and dipteran

287 larvae comprised the largest numbers of infaunal macroinvertebrates inhabiting

288 periphyton. Larger beetles, dragonfly larvae and snails were less numerous in periphyton

289 and found at fewer sites.

290 Sites spanned a wide range of hydrological and nutrient levels (Table 1), and time

291 since flooding was positively correlated with periphyton TP (Spearman correlation: $r_{s}=$

292 0.68). Consistent with several other studies in the Everglades, many attributes of

293 periphyton were associated with time since flooding and/or periphyton TP (Table 2).

294 Increases in nutrient levels and time since flooding were correlated with decreases in

295 periphyton biomass, periphyton volume and the relative abundances of bluegreen and

296 filamentous bluegreen algae, but also with increases in organic content, chlorophyll $a$

297 concentration, and the relative abundances of green algae and diatoms. The density of

298 omnivores increased coincident with nutrient levels and (to a lesser extent) recovery time

299 following drought, while infaunal and herbivore densities did not exhibit strong

300 correlations with either variable (Table 2; Figs. 2 and 3).

301 A comparison of model BIC values indicated that one model (Model 6 in

302 Supporting Information Appendix S2) was preferred to the others (the difference between 
303 the BIC of this model and the next best model was >2) (Table 3). Two other models

304 (Model 1 and Model 7 in Supporting Information Appendix S2) had slightly higher BIC

305 values, but only Model 6 and Model 1 showed adequate absolute fit to the data (Bollen-

306 Stine chi-square tests were not statistically significant at the 0.05 level; Table 3 ).

307 In Model 6 (Fig. 4), changes in periphyton biomass and community structure,

308 driven by increasing phosphorus, are transmitted to omnivores indirectly. Increases in

309 the relative abundance of diatoms and green algae, and increases in periphyton biomass,

310 increased infauna density, which in turn had a positive effect on omnivore density.

311 Omnivores had a negative top-down effect on infauna, and infauna had a small but

312 negative effect on periphyton biomass. Both periphyton biomass and the relative

313 abundance of diatoms and green algae were negatively related to herbivore density, while

314 increasing herbivores increased omnivore density with no reciprocal top-down effect.

315 Model 1 (Fig. 5) included only bottom-up effects and incorporated direct effects

316 of periphyton biomass and relative abundance of diatoms and green algae on omnivore

317 density. Direct effects of time since flooding and periphyton TP were generally similar

318 to those in Model 6. Relationships between trophic groups were bottom-up and mostly

319 positive (increases in prey resulted in increases in consumers) or weak, with the

320 exception of herbivores.

$321 \quad$ Some patterns were shared by Model 6 and Model 1. Herbivore density was

322 negatively related to periphyton biomass and the relative abundance of diatoms and green

323 algae in both models. The total effect of periphyton TP was positive for omnivores and

324 herbivores, but was nearly zero for infauna (Table 4). In Model 1 this resulted only from

325 phosphorus's effect on periphyton community structure and biomass, but in Model 6 the 
326 negligible total effect of phosphorus was largely driven by top-down effects. Time since

327 flooding increased infauna density and omnivore density directly, but decreased

328 herbivore density directly in both models. However, time since flooding increased

329 periphyton biomass and decreased the relative abundance of diatoms and green algae,

330 making the total effect of hydrological disturbance negative for infauna and omnivores

331 (Table 4). The effect of time since flooding was more complex for herbivores. In Model

3326 , the negative effect was caused by a strong direct path and multiple indirect effects. In

333 Model 1, the total effect was weaker, and the negative direct effect was moderated by

334 positive indirect effects through periphyton. The total effects of periphyton TP on

335 periphyton and consumers were larger than those of time since flooding in both models

336 (Table 4), with the exception of infauna density.

339 Discussion

$340 \quad$ Using structural equation modeling, we identified two possible mechanistic

341 models describing the effects of nutrient enrichment, disturbance and food-web

342 interactions on small consumers in the Florida Everglades. The best-supported model

343 (Model 6) showed evidence for top-down control of periphyton infauna densities, and

344 suggested that trophic cascades may help maintain periphyton biomass against herbivory

345 in the Everglades. However, the BIC value of Model 1 (a model allowing bottom-up

346 effects only and including omnivory) was only slightly higher, indicating that it also

347 deserves consideration. While other studies have illustrated the importance of

348 hydrological disturbance in shaping temporal trends in Everglades aquatic communities, 
349 our findings emphasize a greater role of nutrient gradients in contributing to consumer

350 densities across large spatial scales in the late wet season, when direct effects of previous

351 drying were relatively weak. Further, the structural equation models identified the effects

352 of food quality (indicated by algal community structure) and food or habitat quantity

353 (indicated by periphyton biomass), allowed effects of nutrient enrichment and hydrology

354 to be disentangled, and provided insight into direct versus indirect effects in this system.

355 Both models incorporated bottom-up effects initiated by increases in nutrients

356 (measured by total phosphorus levels in periphyton). Increasing phosphorus appeared to

357 drive compositional changes in periphyton, including shifts in the dominant algal species,

358 the proportion of organic content and the overall biomass and volume of periphyton.

359 These findings mirror those of several other studies correlating phosphorus addition with

360 increases in the relative abundance of diatoms and green algae and organic content, but

361 decreases in the relative abundance of filamentous bluegreen algae and biomass of

362 bluegreen algae and periphyton (McCormick et al., 1996; Gaiser et al., 2005, 2006). The

363 proportion of periphyton comprised of organic material, diatoms and green algae may

364 reflect food quality since these components are probably more palatable than inorganic

365 components, bluegreen algae or filamentous bluegreen algae (Geddes \& Trexler, 2003).

366 Phosphorus addition increases these palatable elements, but decreases the total organic

367 biomass of periphyton (e.g., food quantity and habitat for infauna).

368 These changes in periphyton quality and quantity appear to be the indirect link

369 between phosphorus enrichment and consumer densities. In both models, infaunal

370 density directly increased with periphyton biomass and the proportion of green algae and

371 diatoms. In Model 1, where primary production was directly linked to omnivore density, 
372 omnivores responded positively to the relative abundance of diatoms and green algae,

373 and negatively to periphyton biomass (although this latter relationship was quite weak in

374 magnitude). This is in contrast to Model 6, in which changes in food are transmitted to

375 omnivores indirectly through infauna and herbivores. Interestingly, periphyton biomass

376 and the relative abundance of diatoms and green algae had strong negative direct effects

377 on herbivore density in both models, generally contrasting with their effects on infauna

378 and omnivores. A possible explanation may be found in the composition of the herbivore

379 community; flagfish comprised a significant portion of the herbivores in our samples and

380 they may be poor competitors (Trexler et al., 2005). Nonetheless, herbivore density

381 actually increased with nutrient enrichment (i.e., the total effect of periphyton TP) due to

382 the indirect pathways via periphyton biomass. Both models indicate that the quality of

383 periphyton is as important as total food biomass, consistent with previous work

384 demonstrating an increased ability of some consumers to feed on palatable elements

385 following a physical break-up in the periphyton mat (Geddes \& Trexler, 2003).

386 In the Everglades, the maintenance of large expanses of periphyton mats and

387 apparent limits on infaunal density even in the face of nutrient enrichment may be

388 evidence for a trophic cascade (Turner et al., 1999; Liston, 2006). Trophic cascades are

389 widespread in aquatic systems (Shurin et al., 2002), often driven by predation of

390 macroinvertebrates by fish (e.g., Wootton \& Power, 1993). Few studies of top-down

391 effects have been conducted in wetlands, but some show that small fish and insect

392 predators can reduce invertebrate numbers (Batzer, 1998; Peck \& Walton, 2008), while

393 others have not found effects of small predators (Corti et al., 1997). Empirical support

394 for trophic cascades in the Everglades has been lacking (Dorn, Trexler, \& Gaiser, 2006; 
395 Chick, Geddes, \& Trexler, 2008). In the current study, small fish and invertebrates, but

396 not infauna, increased with nutrients, a pattern potentially consistent with a trophic

397 cascade based on predictions from food web theory (Power, 1992). The relative strength

398 of Model 6 suggests that both bottom-up and top-down forces are important in shaping

399 the densities of basal consumers in the Everglades. Like all the models considered,

400 Model 6 includes bottom-up relationships between primary production (periphyton) and

401 higher trophic levels. Increases in phosphorus levels drive changes in periphyton

402 community structure, increasing the proportion of highly palatable algal species while

403 simultaneously reducing the total organic biomass of periphyton. Model 6 assumes that

404 these changes in primary production are transmitted indirectly, through primary

405 consumers (infaunal macroinvertebrates and herbivorous fish, invertebrates, and

406 tadpoles), to omnivorous fish and invertebrates. Omnivores, in turn, limit infauna

407 density, and infauna density has a negative effect on periphyton biomass. These

408 relationships are likely to underpin the pattern of increasing omnivore density, but not

409 infauna density, with nutrient enrichment (e.g., Fig. 3). The positive effect of omnivores

410 (through macroinvertebrate infauna) on periphyton biomass implies that a trophic cascade

411 helps maintain periphyton mats, but herbivores may simultaneously act to stimulate

412 periphyton growth (see below), indicating that multiple factors are important in

413 controlling periphyton biomass.

414 This contrasts with the exclusively bottom-up structure of Model 1. The fact that

415 two very different models had similar support may be explained by the role of omnivory.

416 Model 1 allows for omnivores to feed directly on periphyton, and this may result in

417 similar net effects of periphyton TP as are found in Model 6 in which omnivory is 
418 removed. Trophic cascades are generally thought to be limited by omnivory (Polis \&

419 Strong, 1996), and could also be restricted in the Everglades by the associative resistance

420 afforded palatable algae by the physical or algal composition of periphyton mats (Geddes

$421 \&$ Trexler, 2003; Chick et al., 2008). However, past studies have not found support that

422 omnivorous fishes and invertebrates assimilate more periphyton as nutrients increase

423 (Williams \& Trexler, 2006).

$424 \quad$ Herbivorous small fish and invertebrates played a different role than other

425 consumer groups in both models. Herbivore density had a positive effect on omnivore

426 density, presumably via predation where predators were unable to limit prey numbers.

427 The similar size of individuals in the omnivore and herbivore groups may have prevented

428 top-down control; some of the herbivores may have been too large or well-defended for

429 the small omnivores to consume them. In Model 6, herbivores had a positive top-down

430 effect on periphyton biomass, seemingly inconsistent with an expected predator-prey

431 relationship. While a negative effect of predation may be more expected, positive effects

432 could occur through nutrient regeneration (Geddes \& Trexler, 2003).

433 Previous studies of Everglades fauna have frequently found negative correlations

434 between small fish and/or macroinvertebrate densities and measures of disturbance

435 (Trexler et al., 2002, 2005; Liston, 2006). The direct effect of time since flooding was

436 positive for infauna and omnivore density in both models, suggesting their numbers

437 increased with recovery time following droughts. However, the opposite pattern was

438 found for herbivores, probably stemming from dominance of flagfish, which tend to

439 decrease with time following droughts (Trexler et al., 2005). Time since flooding was

440 important in contributing to algal community structure, reducing the proportion of 
441 diatoms and green algae. Our results are potentially inconsistent with a previous study

442 (Gottlieb et al., 2006) reporting higher relative abundance of diatoms in long-hydroperiod

443 sites, but that study did not separate effects of phosphorus from those of hydrology,

444 which tend to be correlated. Despite a negative direct effect, the overall correlation

445 between time since flooding and the relative abundance of green algae and diatoms was

446 positive, possibly explaining the differences in results between studies. Effects of

447 hydrological disturbance were somewhat weaker than the effects of nutrient enrichment,

448 and the total effect of time since flooding was negative for all three consumer groups as a

449 result of numerous indirect effects. Reduced effects of hydrology relative to nutrients in

450 this study may have resulted from focusing on spatial, rather than temporal, variability

451 and by sampling at the end of the wet season when few sites had been recently dry. This

452 study also used partial regression coefficients to estimate effects of hydrology and

453 nutrients, possibly resulting in different findings than studies relying on correlation alone.

454 Structural equation models can provide important advances in understanding

455 Everglades food webs. However, there are some shortcomings of our study. As is the

456 case for all studies examining open, natural food webs, a limitation of our analysis is that

457 models were necessary simplifications of the true food web. We were unable to include

458 the effects of larger predators, which may have exerted further top-down control on

459 consumers, and detritus-based components of the food web. Effects of predatory fish,

460 such as gar, may actually be included in direct effects of time since flooding, since they

461 are limited to deeper refugia when water levels are low (Chick, Ruetz, \& Trexler, 2004).

462 In addition, although we gained some resolution by categorizing consumers into three

463 groups based on size and diet, individual species may exhibit unique and contrasting 
464 patterns not fully described by this analysis. For example, Liston (2006) identified

465 effects of hydrology and/or nutrient levels on certain infaunal groups that were

466 sometimes at odds with patterns observed for infauna as a whole. Finally, our study did

467 not incorporate sites with phosphorus levels greatern than $760 \mu \mathrm{g} \mathrm{g}^{-1}$ dry periphyton

468 tissue; at higher levels periphyton mats can completely disappear and densities of fish

469 and macroinvertebrates can be reduced (King \& Richardson, 2007; Liston et al., 2008;

470 Rejmánková, Macek, \& Epps, 2008). Future research should address food-web structure

471 at artificially high nutrient levels, and ideally incorporate larger predatory fishes and

472 wading birds as a fourth trophic level.

473 By using a multi-model, structural equation modeling approach (Grace, 2006),

474 this study provides insight into direct and indirect effects and the apparently limited role

475 of top-down control in shaping consumer densities. To our knowledge, this is the first

476 such analysis of a natural wetlands food web incorporating multiple trophic levels. Our

477 results should guide future research to on the mechanisms underlying our proposed causal

478 pathways.

479

480

481 Acknowledgments

482 This work as made possible by Peter Kalla and Daniel Scheidt of the U. S. Environmental

483 Protection Agency (US EPA) and Jennifer Richards of Florida International University

484 (FIU), who managed and coordinated our research program and assured adequate funding

485 and research support for this project. We thank Mike Cuoto, Albert Gonzales, Charles

486 Molnar, Angela Marino, Christine Taylor and Franco Tobias for collecting and 
487 processing samples, Charles Goss for providing hydrological data, and Aaron Parker for

488 providing the map. This research was conducted as part of the US EPA's (Region 4,

489 Science and Ecosystem Support Division and Water Management Divison) R-EMAP

490 project (EPA 904-R-07-001), which was jointly funded by the US EPA and the

491 Everglades National Park (ENP) under cooperative agreement number H5297-05-0088

492 between FIU and ENP. This research was enhanced by collaborations with the Florida

493 Coastal Everglades Long-Term Ecological Research program (funded by the National

494 Science Foundation, DBI-0620409 and DEB-9910514). The research was conducted in

495 accord with FIU animal care guidelines. This is contribution \#XXX of the Southeast

496 Environmental Research Center.

497

498

499 References

500 Batzer D.P. (1998) Trophic interactions among detritus, benthic midges, and predatory

501 fish in a freshwater marsh. Ecology, 79, 1688-1698. doi: 10.1890/0012-

502 9658(1998)079[1688:TIADBM]2.0.CO;2

503 Burnham, K. P., \& Anderson, D. R. (2002) Model Selection and Multimodel Inference:

504 A Practical Information-Theoretic Approach, $2^{\text {nd }}$ Edition. Springer-Verlag, New

$505 \quad$ York.

506 Byrne B.M. (2000) Structural Equation Modeling with AMOS: Basic Concepts,

507 Applications, and Programming. Lawrence Erlbaum Associates, Mahwah, NJ,

$508 \quad$ USA. 
509 Chase J.M. (2003) Strong and weak trophic cascades along a productivity gradient.

510 Oikos, 101, 187-195. doi: 10.1034/j.1600-0706.2003.12062.x

511 Chick J.H., Geddes P., \& Trexler J.C. (2008) Periphyton mat structure mediates trophic

512 interactions in a subtropical marsh. Wetlands, 28, 378-389. doi: 10.1672/07-121.1

513 Chick J.H., Ruetz C.R., III, \& Trexler J.C. (2004) Spatial scale and abundance patterns of $514 \quad$ large fish communities in freshwater marshes of the Florida Everglades.

$515 \quad$ Wetlands, 24,652-664. doi:

$516 \quad 10.1672 / 02775212(2004) 024[0652: S S A A P O] 2.0 . C O ; 2$

517 Claeskens G. \& Hjort N.L. (2008) Model Selection and Model Averaging. Cambridge

$518 \quad$ University Press, New York.

519 Corti D., Kohler S.L., \& Sparks R.E. (1997) Effects of hydroperiod and predation on a 520 Mississippi River floodplain invertebrate community. Oecologia, 109, 154-165. $521 \quad$ doi: $10.1007 / \mathrm{s} 004420050070$

522 Davis S.M. (1994) Phosphorus inputs and vegetation sensitivity in the Everglades. In:

523 Everglades: The Ecosystem and Its Restoration (Eds. S.M. Davis \& J.C. Ogden), 524 pp. 357-378. St. Lucie Press, Delray Beach, FL, USA.

525 Davis S.M. \& Ogden J.C. (Eds.) (1994) Everglades: The Ecosystem and Its Restoration. 526 St. Lucie Press, Delray Beach, FL, USA.

527 Dorn N.J. (2008) Colonization and reproduction of large macroinvertebrates are 528 enhanced by drought-related fish reductions. Hydrobiologia, 605, 209-218. doi:

$529 \quad 10.1007 / \mathrm{s} 10750-008-9355-7$ 
530 Dorn N.J., Trexler J.C., \& Gaiser E.E. (2006) Exploring the role of large predators in 531 marsh food webs: Evidence for a behaviorally-mediated trophic cascade.

532 Hydrobiologia, 569, 375-386. doi: 10.1007/s10750-006-0143-y

533 Elmhagen B. \& Rushton S.P. (2007) Trophic control of mesopredators in terrestrial 534 ecosystems: Top-down or bottom-up? Ecology Letters, 10, 197-206. doi: $535 \quad 10.1111 / \mathrm{j} .1461-0248.2006 .01010 . \mathrm{x}$

536 Gaiser E.E., Childers D.L., Jones R.D., Richards J.H., Scinto L.J., \& Trexler J.C. (2006)

537 Periphyton responses to eutrophication in the Florida Everglades: Cross-system

538 patterns of structural and compositional change. Limnology and Oceanography, 539 51, 617-630.doi: 10.4319/lo.2006.51.1_part_2.0617

540 Gaiser E.E., Trexler J.C., Richards J.H., Childers D.L., Lee D., Edwards A.L., Scinto

541 L.J., Jayachandran K., Noe G.B., \& Jones R.D. (2005) Cascading ecological 542 effects of low-level phosphorus enrichment in the Florida Everglades. Journal of 543 Environmental Quality, 34, 717-723. doi:10.2134/jeq2005.0717

544 Geddes P. \& Trexler J.C. (2003) Uncoupling of omnivore-mediated positive and negative 545 effects on periphyton mats. Oecologia, 136, 585-595. doi: 10.1007/s00442-003-

$546 \quad 1294-4$

547 Gotelli N.J. \& Ellison A.M. (2006) Food-web models predict species abundances

548 in response to habitat change. PLoS Biology, 4, 1869-1873. doi:

$549 \quad$ 10.1371/journal.pbio.0040324

550 Gottlieb A.D., Richards J.H., \& Gaiser E.E. (2006) Comparative study of periphyton 551 community structure in long and short-hydroperiod Everglades marshes.

552 Hydrobiologia, 569, 195-207. doi: 10.1007/s10750-006-0132-1 
553 Grace J.B. (2006) Structural Equation Modeling and Natural Systems. Cambridge

$554 \quad$ University Press, New York.

555 Gunderson, L. H. (1994) Vegetation of the Everglades: Determinants of community

556 composition. In: Everglades: The System and Its Restoration (Eds. S. M. Davis \&

557 J. C. Ogden), pp. 323-340. St. Lucie Press, Boca Raton, FL.

558 Gunderson L.H. \& Loftus W.F. (1993) The Everglades. In: Biodiversity of the

559 Southeastern United States: Lowland Terrestrial Communities (Eds. W.H. Martin,

560 S.G. Boyce, \& A.C. Echternacht), pp. 199-225. John Wiley \& Sons, Inc., New

$561 \quad$ York.

562 Johnson M.L., Huggins D.G., \& DeNoyelles F., Jr. (1991) Ecosystem modeling with

563 Lisrel: A new approach for measuring direct and indirect effects. Ecological

$564 \quad$ Applications, 1, 383-398. doi: 10.2307/1941898

565 Jordan C.F., Coyne S., \& Trexler J.C. (1997) Sampling fishes in vegetated habitats:

566 Effects of habitat structure on sampling characteristics of the 1- $\mathrm{m}^{2}$ throw trap.

567 Transactions of the American Fisheries Society, 126, 1012-1020. doi:

$568 \quad 10.1577 / 1548-8659(1997) 126<1012:$ SFIVHE $>2.3 . C O ; 2$

569 King R.S. \& Richardson C.J. (2007) Subsidy-stress response of macroinvertebrate

570 community biomass to a phosphorus gradient in an oligotrophic wetland

571 ecosystem. Journal of the North American Benthological Society, 26, 491-508.

572 doi: $10.1899 / 06-002 R .1$

573 Kline R.B. (2005) Principles and Practice of Structural Equation Modeling, $2^{\text {nd }}$ edn. The

574 Guilford Press, New York.Kneitel J.M. \& Chase J.M. (2004) Disturbance, 
575 predator, and resource interactions alter container community composition.

576 Ecology, 85, 2088-2093. doi: 10.1890/03-3172

577 Liston S.E. (2006) Interactions between nutrient availability and hydroperiod shape

578 macroinvertebrate communities in Florida Everglades marshes. Hydrobiologia,

$579 \quad 569,343-357$. doi: 10.1007/s10750-006-0141-0

580 Liston S.E., \& Trexler J.C. (2005) Spatial and temporal scaling of macroinvertebrate

$581 \quad$ communities inhabiting floating periphyton mats in the Florida Everglades.

$582 \quad$ Journal of the North American Benthological Society, 24,832-844.

583 Liston S.E., Newman S., \& Trexler J.C. (2008) Macroinvertebrate community response

584 to eutrophication in an oligotrophic wetland: An in situ mesocosm experiment.

$585 \quad$ Wetlands, 28, 686-694. doi: 10.1672/07-224.1

586 Loftus, W. F. (1999) Accumulation and fate of mercury in an Everglades food web. Ph.D.

587 Dissertation, Florida International University, Miami, 295pp.

588 Marks J.C., Power M.E., \& Parker M.S. (2000) Flood disturbance, algal productivity, and

589 interannual variation in food chain length. Oikos, 90, 20-27. doi: 10.1034/j.1600-

$590 \quad$ 0706.2000.900103.x

591 McCormick P.V., Rawlik P.S., Lurding K., Smith E.P., \& Sklar F.H. (1996) Periphyton-

592 water quality relationships along a nutrient gradient in the northern Florida

593 Everglades. Journal of the North American Benthological Society, 15, 433-449.

594 McCormick P.V., Shuford R.B.E., III, \& Rawlik P.S. (2004) Changes in

595 macroinvertebrate community structure and function along a phosphorus gradient

596 in the Florida Everglades. Hydrobiologia, 529, 113-132. doi: 10.1007/s10750-

$597 \quad 004-5737-7$ 
598 Menge B.A. \& Sutherland J.P. (1987) Community regulation: Variation in disturbance,

599 competition, and predation in relation to environmental stress and recruitment.

600 The American Naturalist, 130, 730-757. doi: 10.1086/284741

601 Morin P. J. (1999) Community Ecology. Blackwell Science, Malden, MA

602 Pace M.L., Cole J.J., Carpenter S.R., \& Kitchell J.F. (1999) Trophic cascades revealed in

603 diverse ecosystems. TREE, 14, 483-488. doi:10.1016/S0169-5347(99)01723-1

604 Peck G.W. \& Walton W.E. (2008) Effect of mosquitofish (Gambusia affinis) and sestonic

605 food abundance on the invertebrate community within a constructed treatment

606 wetland. Freshwater Biology, 53, 2220-2233. doi: 10.1111/j.1365-

$607 \quad 2427.2008 .02048 . x$

608 Polis G.A. \& Strong D.R. (1996) Food web complexity and community dynamics. The

609 American Naturalist, 147, 813-846. doi: 10.1086/285880

610 Power M.E. (1992) Do plants have primacy? Ecology, 73, 733-746. doi:

$611 \quad 10.2307 / 1940153$

612 Power M.E., Parker M.S., \& Wootton J.T. (1996) Disturbance and food chain length in 613 rivers. In: Food Webs: Integration of Patterns and Dynamics (Eds. G.A. Polis \&

614 K.O. Winemiller), pp. 286-297. Chapman \& Hall, New York.

615 Rader R.B. \& Richardson C.J. (1994) Response of macroinvertebrates and small fish to 616 nutrient enrichment in the northern Everglades. Wetlands, 14, 134-146.

617 Rejmánková E., Macek P., \& Epps K. (2008) Wetland ecosystem changes after three 618 years of phosphorus addition. Wetlands, 28, 914-927. doi: 10.1672/07-150.1 
619 Riginos C. \& Grace J.B. (2008) Savanna tree density, herbivores, and the herbaceous

620 community: Bottom-up vs. top-down effects. Ecology, 89, 2228-2238. doi:

$621 \quad 10.1890 / 07-1250.1$

622 Scheidt D.J., \& Kalla P.I. (2007) Everglades ecosystem assessment: water management

623 and quality, eutrophication, mercury contamination, soils and habitat: monitoring

624 for adaptive management: a R-EMAP status report. USEPA Region 4, Athens,

625 GA. EPA 904-R-07-001. 98 pp.

626 Shurin J.B., Borer E.T., Seabloom E.W., Anderson K., Blanchette C.A., Broitman B.,

627 Cooper S.D., \& Halpern B.S. (2002) A cross-ecosystem comparison of the

628 strength of trophic cascades. Ecology Letters, 5, 785-791. doi: 10.1046/j.1461-

$629 \quad$ 0248.2002.00381.x

630 Stevens D. L., \& Olsen A.R. (2003) Variance estimation for spatially balanced samples

631 of environmental resources. Environmetrics, 14, 593-610. doi: 10.1002/env.606.

632 Stevenson R. J., McCormick P.V., \& Frydenborg R. (2002) Methods for evaluating

633 wetland condition: \#11 Using algae to assess environmental conditions in

634 wetlands. EPA-822-R-02-021. United States Environmental Protection Agency,

635 Office of Water. Washington, DC.

636 Thomas S., Gaiser E. E., Gantar M., \& Scinto L. J. (2006) Quantifying the responses of

637 calcareous periphyton crusts to rehydration: A microcosm study (Florida

638 Everglades). Aquatic Botany, 84, 317-323. doi:10.1016/j.aquabot.2005.12.003

639 Trexler, J. C., \& Goss C. W. 2009. Aquatic fauna as indicators for Everglades restoration:

640 Applying dynamic targets in assessments. Ecological Indicators 9S:S108-S119.

$641 \quad$ doi:10.1016/j.ecolind.2008.11.001 
642 Trexler J.C., Loftus W.F., Jordan F., Chick J.H., Kandl K.L., McElroy T.C., \& Bass O.L., 643 Jr. (2002) Ecological scale and its implications for freshwater fishes in the Florida 644 Everglades. In: The Everglades, Florida Bay, and Coral Reefs of the Florida 645 Keys: An Ecosystem Sourcebook (Eds. J.W. Porter \& K.G. Porter), pp. 153-181. 646 CRC Press, Boca Raton, FL, USA.

647 Trexler J.C., Loftus W.F., \& Perry S. (2005) Disturbance frequency and community 648 structure in a twenty-five year intervention study. Oecologia, 145, 140-152. doi: $10.1007 / \mathrm{s} 00442-005-0094-4$

650 Turner A.M., Trexler J.C., Jordan C.F., Slack S.J., Geddes P., Chick J.H., \& Loftus W.F. (1999) Targeting ecosystem features for conservation: Standing crops in the Florida Everglades. Conservation Biology, 13, 898-911. doi: 10.1046/j.15231739.1999.97513.x

654 Wellborn G.A., Skelly D.K., \& Werner E.E. (1996) Mechanisms creating community 655 structure across a freshwater habitat gradient. Annual Review of Ecology and 656 Systematics, 27, 337-363. doi: 10.1146/annurev.ecolsys.27.1.337

657 Williams A.J. \& Trexler J.C. (2006) A preliminary analysis of the correlation of food658 web characteristics with hydrology and nutrient gradients in the southern 659 Everglades. Hydrobiologia, 569, 493-504. doi: 10.1007/s10750-006-0151-y

660 Winemiller K.O. (1996) Factors driving temporal and spatial variation in aquatic 661 floodplain food webs. In: Food Webs: Integration of Patterns and Dynamics (Eds. 662 G.A. Polis \& K.O. Winemiller), pp. 298-312. Chapman \& Hall, New York. 
663 Wootton J.T. (1994a) The nature and consequences of indirect effects in ecological

664 communities. Annual Review of Ecology and Systematics, 25, 443-466. doi:

$665 \quad$ 10.1146/annurev.es.25.110194.002303

666 Wootton J.T. (1994b) Predicting direct and indirect effects: An integrated approach using

667 experiments and path analysis. Ecology, 75, 151-165. doi: 10.2307/1939391

668 Wootton J.T., Parker M.S., \& Power M.E. (1996) Effects of disturbance on river food

$669 \quad$ webs. Science, 273, 1558-1561. doi: 10.1126/science.273.5281.1558

670 Wootton J.T. \& Power M.E. (1993) Productivity, consumers, and the structure of a river

671 food chain. Proceedings of the National Academy of Sciences of the United States

$672 \quad$ of America, 90, 1384-1387.

673

674 
Table 1 Descriptive statistics for environmental gradients and consumer densities $(n=$ 28)

\begin{tabular}{lccc}
\hline Variables & $\begin{array}{c}\text { Minimum } \\
\text { Value }\end{array}$ & $\begin{array}{c}\text { Maximum } \\
\text { Value }\end{array}$ & Mean \pm SE \\
\hline Periphyton TP $\left(\mu \mathrm{g} \cdot \mathrm{g} \mathrm{dry}^{-1}\right)$ & 53 & 760 & $272 \pm 39$ \\
Time since flooding (days) & 160 & 2164 & $611 \pm 134$ \\
Periphyton biomass (AFDM) $\left(\mathrm{g} \cdot \mathrm{m}^{-2}\right)$ & 4 & 540 & $107 \pm 29$ \\
Small omnivore density (number $\left.\cdot \mathrm{m}^{-2}\right)$ & 1 & 318 & $35 \pm 11$ \\
Small herbivore density (number $\left.\cdot \mathrm{m}^{-2}\right)$ & 0.0 & 9.7 & $1.5 \pm 0.41$ \\
Periphyton infauna density $\left(\mathrm{number} \cdot \mathrm{m}^{-2}\right)$ & 409 & 105,123 & $\begin{array}{c}37,562 \pm \\
5,622\end{array}$
\end{tabular}


Table 2 Spearman correlations between major environmental gradients (time since flooding and periphtyon total phosphorus [TP]) and periphyton characteristics and consumer densities $(n=28)$

\begin{tabular}{lcc}
\hline & $\begin{array}{c}\text { Time since } \\
\text { flooding, } \boldsymbol{r}_{s}\end{array}$ & $\begin{array}{c}\text { Periphtyon } \\
\text { TP, } \boldsymbol{r}_{\boldsymbol{s}}\end{array}$ \\
\hline Total periphyton volume $(\mathrm{ml})$ & -0.59 & -0.88 \\
Total periphyton aerial cover $(\%)$ & -0.67 & -0.87 \\
Periphyton biomass $(\mathrm{AFDM})\left(\mathrm{g} \cdot \mathrm{m}^{-2}\right)$ & -0.68 & -0.92 \\
Percent organic content $(\%)$ & +0.64 & +0.82 \\
Percent carbon $(\%)$ & +0.66 & +0.84 \\
Percent nitrogen $(\%)$ & +0.64 & +0.86 \\
Chlorophyll $a$ concentration $\left(\mu \mathrm{g} \cdot \mathrm{g} \mathrm{dry}{ }^{-1}\right)$ & +0.57 & +0.78 \\
Chlorophyll $a$ density $\left(\mu \mathrm{g} \cdot \mathrm{m}^{-2}\right)$ & -0.65 & -0.88 \\
$\begin{array}{l}\text { Relative abundance of non-filamentous bluegreen } \\
\text { algae }\end{array}$ & -0.42 & -0.53 \\
Relative abundance of filamentous bluegreen algae & -0.43 & -0.80 \\
Relative abundance of green algae & +0.51 & +0.61 \\
Relative abundance of diatoms & +0.30 & +0.50 \\
Small omnivore density $\left(\mathrm{number} \cdot \mathrm{m}^{-2}\right)$ & +0.31 & +0.65 \\
Small herbivore density $\left(\right.$ number $\cdot \mathrm{m}^{-2}$ ) & +0.20 & +0.29 \\
Periphyton infauna density $\left(\mathrm{number} \cdot \mathrm{m}^{-2}\right.$ ) & -0.02 & +0.03
\end{tabular}


Table 3 Comparison of structural equation models (see also detailed descriptions in Supporting Information Appendix S2). The BIC and Bollen-Stine chi-square p-values of the best models are in bold

\begin{tabular}{|c|c|c|c|c|c|c|c|c|}
\hline Model & $\begin{array}{l}\text { Infauna - } \\
\text { Periphyton }\end{array}$ & $\begin{array}{l}\text { Herbivores - } \\
\text { Periphyton }\end{array}$ & $\begin{array}{l}\text { Omnivores - } \\
\text { Periphyton }\end{array}$ & $\begin{array}{l}\text { Omnivores - } \\
\text { Infauna }\end{array}$ & $\begin{array}{l}\text { Omnivores - } \\
\text { Herbivores }\end{array}$ & $k^{1}$ & BIC & $\begin{array}{l}\text { Bollen- } \\
\text { Stine } X^{2} P \text { - } \\
\text { value }\end{array}$ \\
\hline 1 & Bottom-up & Bottom-up & Bottom-up & Bottom-up & Bottom-up & 23 & 95.197 & 0.15 \\
\hline 2 & Bottom-up & Bottom-up & & Bottom-up & Bottom-up & 21 & 104.248 & 0.025 \\
\hline 3 & Bottom-up & Bottom-up & & Bottom-up & & 20 & 117.951 & 0.004 \\
\hline 4 & Bottom-up & Bottom-up & Bottom-up & Bottom-up & & 22 & 106.133 & 0.027 \\
\hline 5 & $\begin{array}{l}\text { Bottom-up } \\
\& \text { Top-down }\end{array}$ & $\begin{array}{l}\text { Bottom-up \& } \\
\text { Top-down }\end{array}$ & & $\begin{array}{c}\text { Bottom-up \& } \\
\text { Top-down }\end{array}$ & & 23 & 108.390 & 0.004 \\
\hline 6 & $\begin{array}{l}\text { Bottom-up } \\
\& \text { Top-down }\end{array}$ & $\begin{array}{l}\text { Bottom-up \& } \\
\text { Top-down }\end{array}$ & & $\begin{array}{l}\text { Bottom-up \& } \\
\text { Top-down }\end{array}$ & Bottom-up & 24 & 92.234 & 0.12 \\
\hline $\begin{array}{c}7 \\
\text { 1 number } \mathrm{c}\end{array}$ & $\begin{array}{l}\text { Bottom-up } \\
\& \text { Top-down } \\
\text { parameters }\end{array}$ & $\begin{array}{l}\text { Bottom-up \& } \\
\text { Top-down }\end{array}$ & $\begin{array}{l}\text { Bottom-up \& } \\
\text { Top-down }\end{array}$ & $\begin{array}{l}\text { Bottom-up \& } \\
\text { Top-down }\end{array}$ & Bottom-up & 27 & 95.781 & 0.033 \\
\hline
\end{tabular}


Table 4 Indirect, direct and total effects of phosphorus enrichment (periphyton TP) and time since flooding for Models 6 and 1

\section{Log Periphyton TP Log Time Since Flooding}

\section{Direct Indirect Total Direct Indirect Total}

\section{Model 6}

Log Periphyton

$$
\begin{array}{cccccc}
-1.95 & +0.21 & -1.74 & +0.04 & -0.06 & -0.02 \\
(-1.02) & (+0.11) & (-0.91) & (+0.02) & (-0.04) & (-0.01)
\end{array}
$$

Biomass

Log Relative

Abundance of

\begin{tabular}{|c|c|c|c|}
\hline $\begin{array}{c}+0.05 \\
(+0.03)\end{array}$ & $\begin{array}{c}+0.05 \\
(+0.03)\end{array}$ & $\begin{array}{c}+0.18 \\
+(0.12)\end{array}$ & $\begin{array}{c}-0.30 \\
(-0.21)\end{array}$ \\
\hline
\end{tabular}

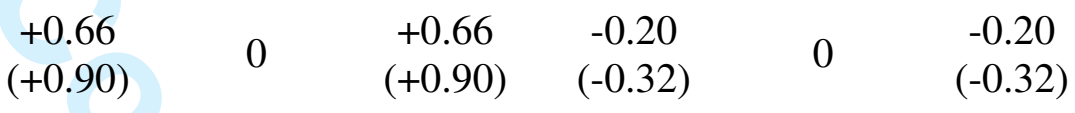

Green Algae

Log Infauna

Density

Log Herbivore

Density

$$
\begin{array}{cccc}
+0.48 & +0.48 & -0.37 & +0.20 \\
(+0.57) & (+0.57) & (-0.51) & (+0.27)
\end{array}
$$

Log Omnivore

Density

$$
+0.83 \quad+0.83
$$

$+0.17$

$-0.37$

$-0.21$

$(+0.68)$

$(+0.68)$

$(+0.16)$

$(-0.36)$

\section{Model 1}

Log Periphyton

$$
-1.77
$$

Biomass$$
0
$$

$-1.77 \quad-0.003$

$(-0.92) \quad(-0.002)$

$-0.003$

Log Relative

Abundance of

$$
+0.66
$$

0

$\begin{array}{cc}+0.66 & -0.20 \\ (+0.90) & (-0.32)\end{array}$

0

$-0.20$

Diatoms + (+0.90)

$(+0.90) \quad(-0.32)$

Green Algae

Log Infauna

Density

$0 \quad(+0$

$$
+0.06
$$

$+0.06 \quad+0.20$

$-0.33$

$-0.13$

Log Herbivore

Density

0

$+0.03)$
+0.29

$(+0.03)$

$(+0.14)$

$(-0.23)$

$(-0.09)$

Log Omnivore

$$
(+0.36)
$$

$+0.29$

$-0.12$

$+0.05$

$-0.08$

Density

$\begin{array}{cc}+0.88 & +0.88 \\ (+0.71) & (+0.71)\end{array}$

$(-0.18)$

$(+0.07)$

$(-0.11)$

0

$(+0.71)$

$+0.01$

$-0.23$

$-0.24$

Standardized coefficients are shown in parentheses. 


\section{Figure Legends}

Fig. 1 Map of the study area with the location of sampling sites in the Florida Everglades

Fig. 2 Relationships between consumer densities and time since flooding

Fig. 3 Relationships between consumer densities and periphyton total phosphorus (TP) levels

Fig. 4 Model with the lowest BIC value (Model 6), incorporating bottom-up and topdown effects and no omnivory. All variables were log-transformed. Unstandardized and standardized (in parentheses) path coefficients are shown, along with squared multiple correlation coefficients $\left(R^{2}\right)$ at the upper right corner of each endogenous variable. The bidirectional arrow between periphyton total phosphorus and time since flooding represents their non-causal bivariate covariance (correlation if standardized)

Fig. 5 Model with the second lowest BIC value (Model 1), incorporating bottom-up effects only and omnivory. All variables were log-transformed. Unstandardized and standardized (in parentheses) path coefficients are shown, along with squared multiple correlation coefficients $\left(R^{2}\right)$ at the upper right corner of each endogenous variable. The bidirectional arrow between periphyton total phosphorus and time since flooding represents their non-causal bivariate covariance (correlation if standardized) 
Fig. 1

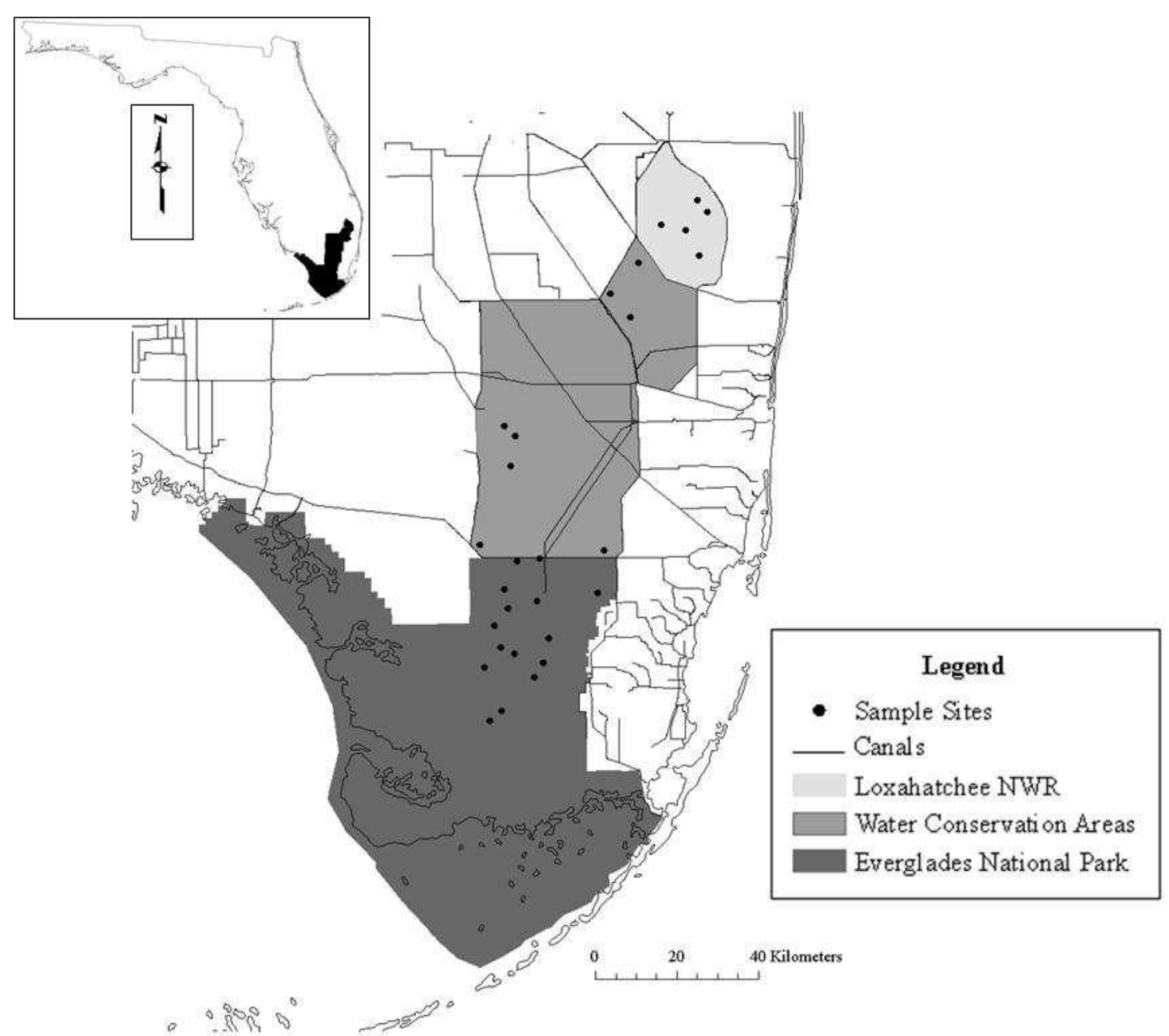

36

37

38

39

40

41

42

43

44

45

46

47

48

49

50

51

52

53

54

55

56

57

58

59

60 
Fig. 2

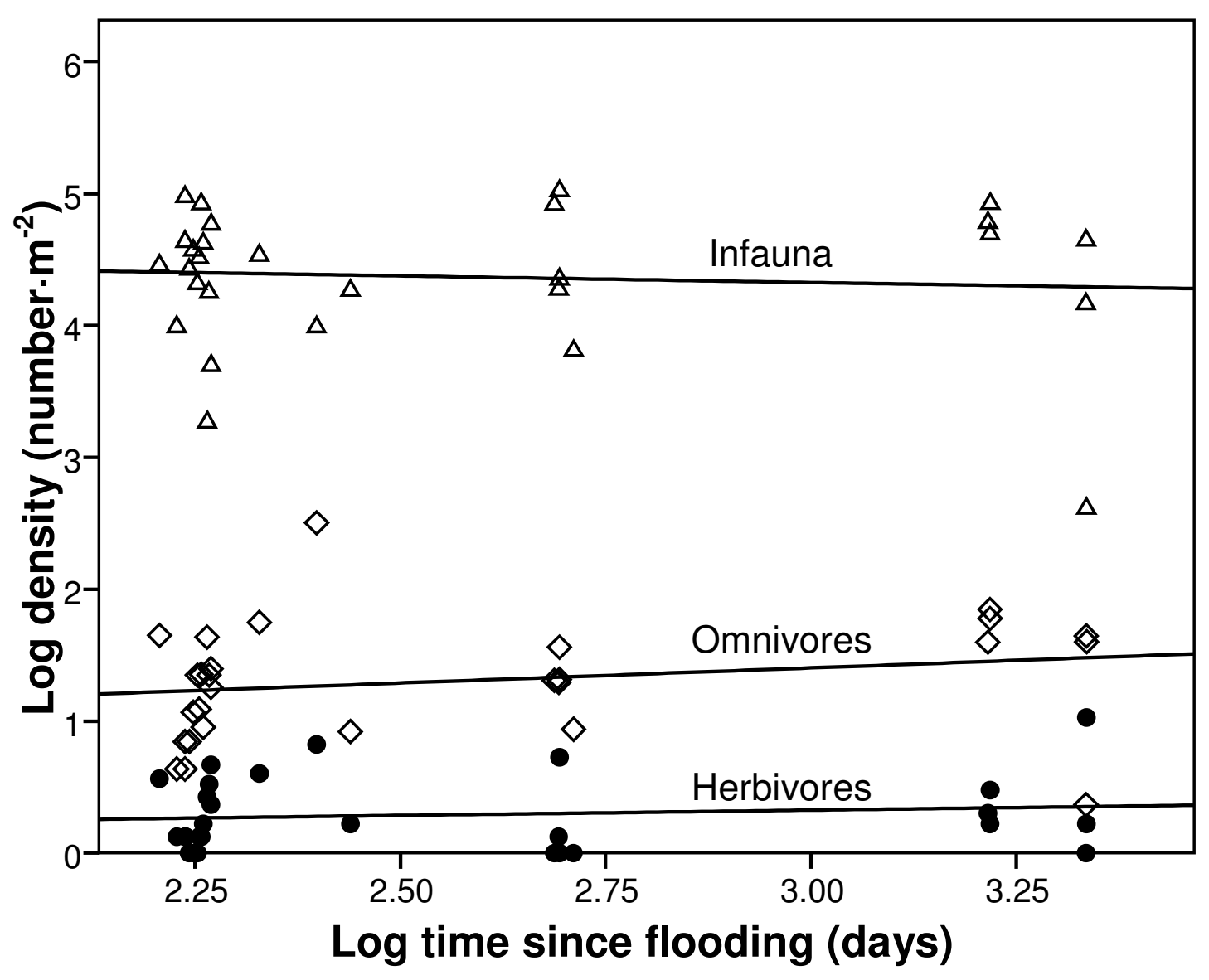


Fig. 3

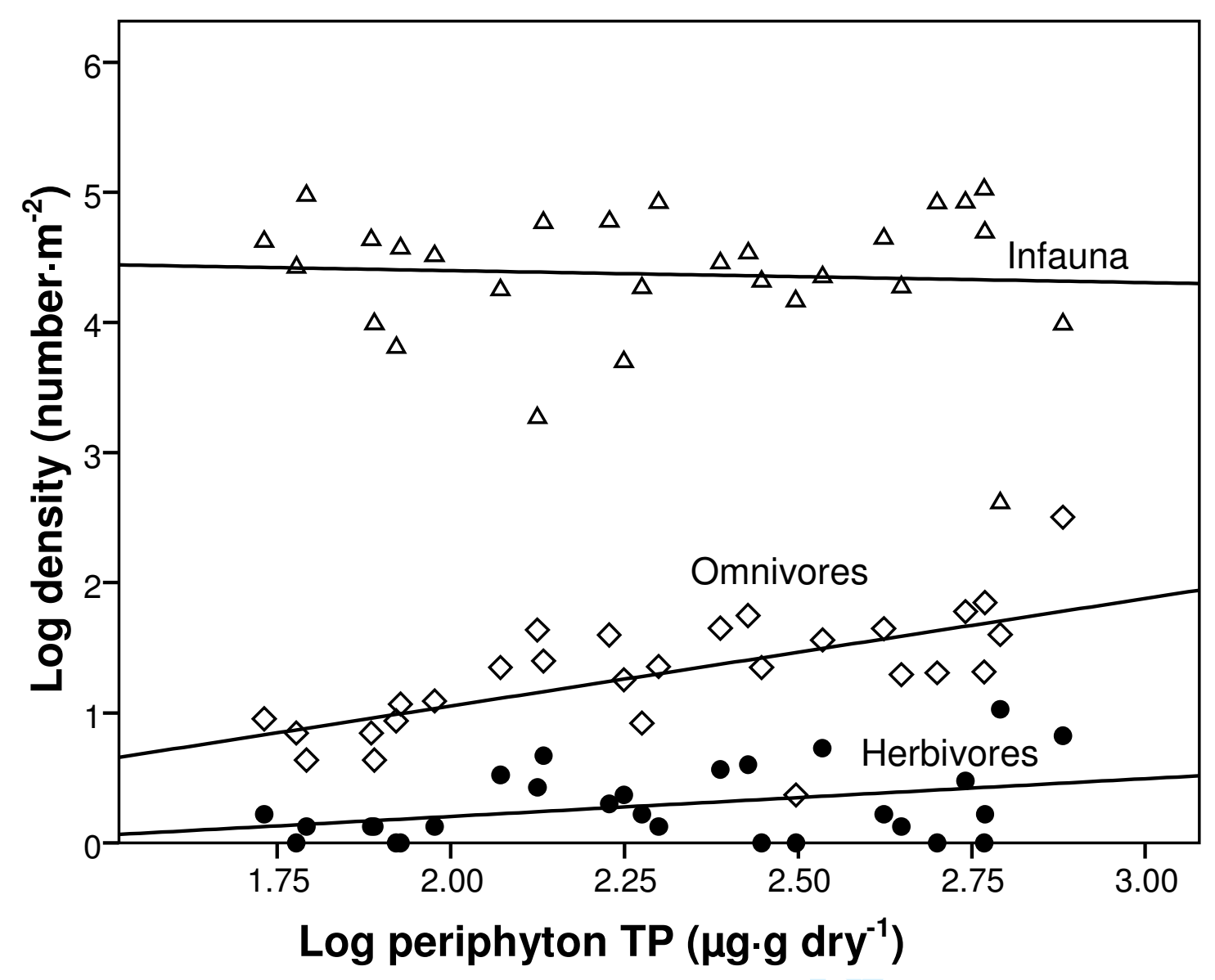


Fig. 4

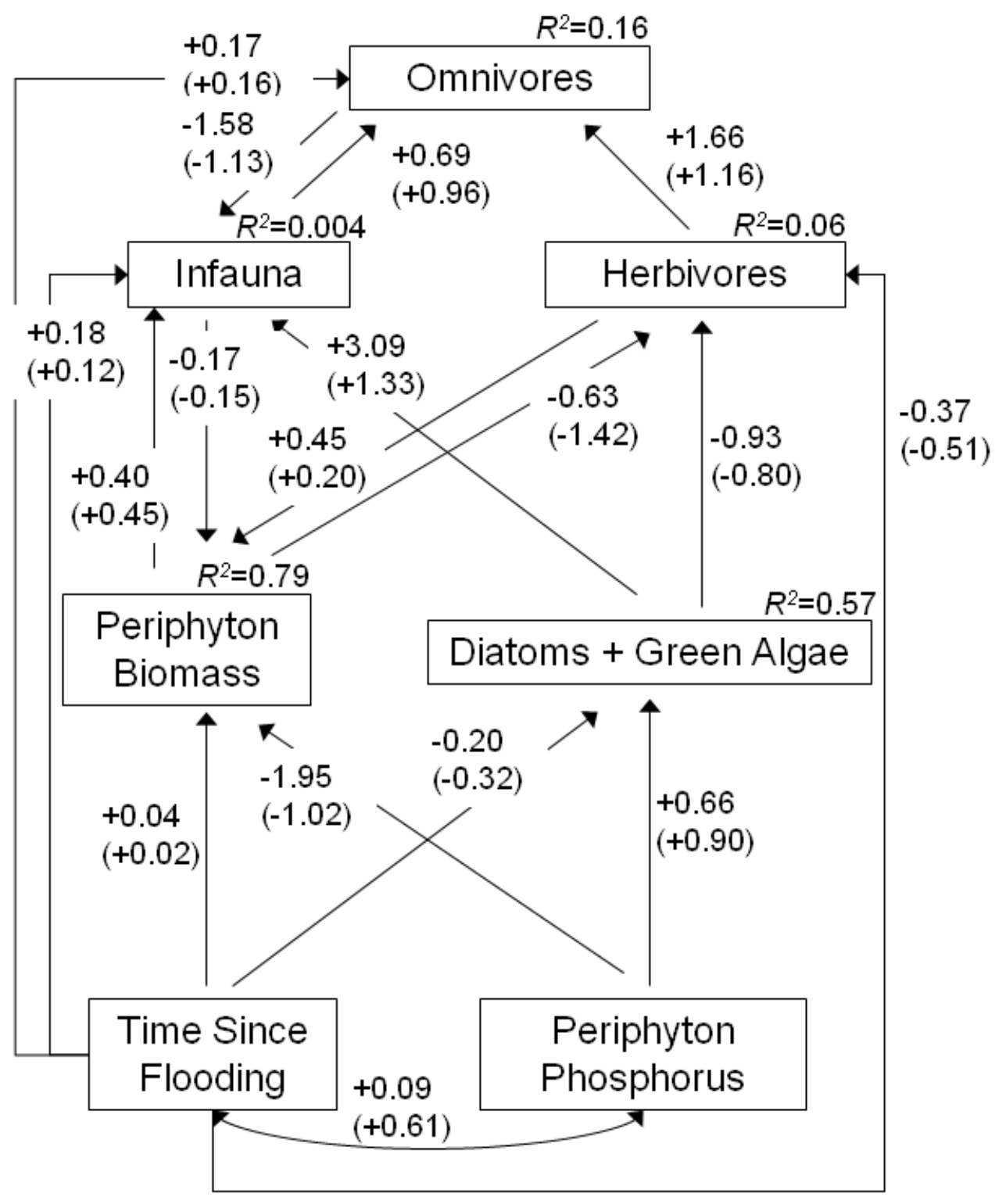


Fig. 5

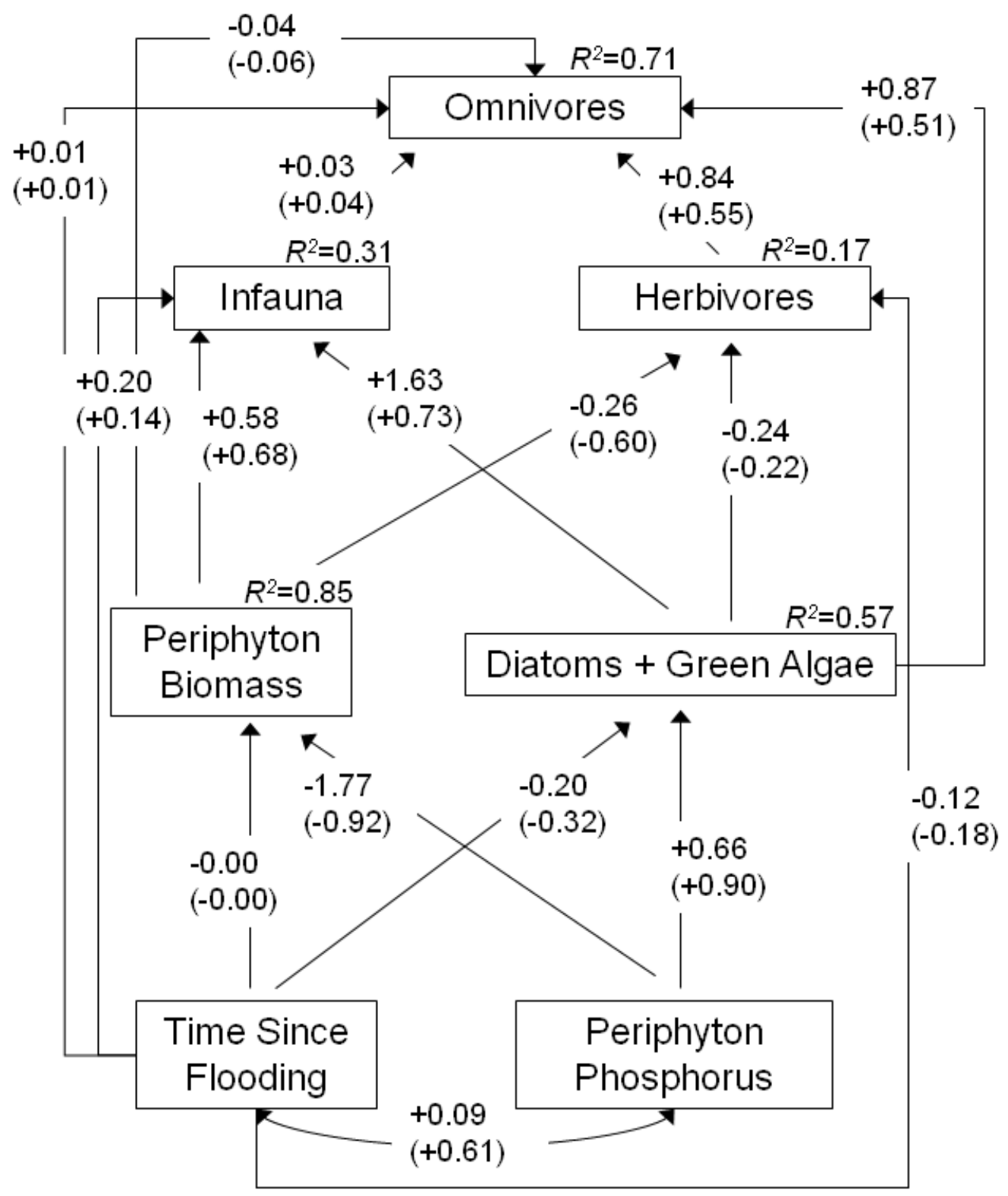

Freshwater Biology 


\section{Supporting Information, Appendix S1}

Table S1 Density and frequency of occurrence of taxonomic groups contributing to trophic categories. We define omnivores as species feeding at more than one trophic level and include several taxa that are carnivores acting as intraguild predators, as well as potentially feeding on herbivores.

\begin{tabular}{|c|c|c|c|}
\hline Taxonomic group & Common name & $\begin{array}{c}\text { Mean density } \\
\left(\# \mathbf{m}^{-2}\right)(\mathrm{SE})\end{array}$ & $\begin{array}{c}\text { Number } \\
\text { of sites }\end{array}$ \\
\hline \multicolumn{4}{|l|}{ Throw-trap omnivores } \\
\hline Palaemonetes paludosus & Grass shrimp & $13(5.4)$ & 20 \\
\hline Heterandria formosa & Least killifish & $7(2.5)$ & 21 \\
\hline Gambusia holbrooki & Mosquitofish & $5(1.5)$ & 23 \\
\hline Lucania goodei & Bluefin killifish & $2.4(0.70)$ & 20 \\
\hline Procambarus fallax & Slough crayfish & $1.7(0.89)$ & 14 \\
\hline Celithemis eponina (larva) & $\begin{array}{l}\text { Halloween pennant } \\
\text { dragonfly }\end{array}$ & $1.0(0.25)$ & 18 \\
\hline Procambarus alleni & Everglades crayfish & $1.0(0.39)$ & 9 \\
\hline Fundulus chrysotus & Golden topminnow & $0.8(0.15)$ & 24 \\
\hline Coenagrionidae (larva) & Damselfly & $0.6(0.26)$ & 16 \\
\hline Pelocoris femoratus & Alligator flea & $0.5(0.18)$ & 14 \\
\hline Elassoma evergladei & $\begin{array}{l}\text { Everglades pygmy } \\
\text { sunfish }\end{array}$ & $0.4(0.14)$ & 9 \\
\hline Lepomis marginatus & Dollar sunfish & $0.4(0.11)$ & 13 \\
\hline Libellula needhami (larva) & $\begin{array}{l}\text { Needham's skimmer } \\
\text { dragonfly }\end{array}$ & $0.3(0.10)$ & 13 \\
\hline Procambarus spp. & $\begin{array}{l}\text { Unknown } \\
\text { procambarid crayfish }\end{array}$ & $0.3(0.14)$ & 9 \\
\hline Fundulus confluentus & Marsh killifish & $0.16(0.063)$ & 7 \\
\hline $\begin{array}{l}\text { Erythemis simplicicollis } \\
\text { (larva) }\end{array}$ & $\begin{array}{l}\text { Eastern pondhawk } \\
\text { dragonfly }\end{array}$ & $0.1(0.11)$ & 2 \\
\hline Belostoma spp. & Giant water bug & $0.10(0.041)$ & 6 \\
\hline $\begin{array}{l}\text { Brachymesia gravida } \\
\text { (larva) }\end{array}$ & $\begin{array}{l}\text { Four-spotted pennant } \\
\text { dragonfly }\end{array}$ & $0.10(0.084)$ & 2 \\
\hline Enneacanthus gloriosus & Bluespotted sunfish & $0.08(0.053)$ & 3 \\
\hline $\begin{array}{l}\text { Coryphaeschna ingens } \\
\text { (larva) }\end{array}$ & $\begin{array}{l}\text { Regal darner } \\
\text { dragonfly }\end{array}$ & $0.04(0.020)$ & 3 \\
\hline Cyprinodon variegatus & Sheepshead minnow & $0.02(0.024)$ & 1 \\
\hline Lepomis punctatus & Spotted sunfish & $0.02(0.017)$ & 2 \\
\hline $\begin{array}{l}\text { Notophthalmus } \\
\text { viridescens }\end{array}$ & Peninsula newt & $0.02(0.024)$ & 1 \\
\hline
\end{tabular}




\begin{tabular}{|c|c|c|c|}
\hline Taxonomic group & Common name & $\begin{array}{c}\text { Mean density } \\
\left(\# \mathbf{~ m}^{-2}\right)(\mathrm{SE})\end{array}$ & $\begin{array}{l}\text { Number } \\
\text { of sites }\end{array}$ \\
\hline Noturus gyrinus & Tadpole madtom & $0.01(0.012)$ & 1 \\
\hline Cybister spp. (larva) & Water beetle & $0.01(0.012)$ & 1 \\
\hline Pseudobranchus axanthus & Dwarf siren & $0.01(0.012)$ & 1 \\
\hline \multicolumn{4}{|l|}{ Throw-trap herbviores } \\
\hline Planorbella spp. & Planorbid snail & $0.6(0.36)$ & 7 \\
\hline Jordanella floridae & Flagfish & $0.4(0.12)$ & 17 \\
\hline Poecilia latipinna & Sailfin molly & $0.18(0.079)$ & 5 \\
\hline Rana spp. (tadpole) & Ranid frog & $0.12(0.075)$ & 3 \\
\hline Coleoptera (adult) & Aquatic beetle & $0.07(0.040)$ & 4 \\
\hline Ephemeroptera (larvae) & Mayfly & $0.06(0.030)$ & 4 \\
\hline Haitia spp. & $\begin{array}{l}\text { Unidentified physid } \\
\text { snail }\end{array}$ & $0.06(0.049)$ & 2 \\
\hline Pomacea paludosa & Apple snail & $0.01(0.012)$ & 1 \\
\hline \multicolumn{4}{|l|}{ Periphyton infauna } \\
\hline Cladocera & $\begin{array}{l}\text { Cladoceran; water } \\
\text { flea }\end{array}$ & $9000(1700)$ & 27 \\
\hline Nematoda & $\begin{array}{l}\text { Nematode; } \\
\text { roundworms }\end{array}$ & $6000(1100)$ & 27 \\
\hline $\begin{array}{l}\text { Chironomidae (larva) } \\
\text { (excluding Tanypodinae) }\end{array}$ & $\begin{array}{l}\text { Chironomid; non- } \\
\text { biting midge }\end{array}$ & $5100(960)$ & 28 \\
\hline Harpacticoida & Harpacticoid copepod & $5000(2200)$ & 21 \\
\hline Acari & Water mite & $5000(1800)$ & 28 \\
\hline Ostracoda & Ostracod & $4000(900)$ & 28 \\
\hline Amphipoda & Amphipod & $900(220)$ & 26 \\
\hline Tanypodinae (larva) & $\begin{array}{l}\text { Chironomid; non- } \\
\text { biting midge }\end{array}$ & $800(150)$ & 27 \\
\hline Dasyhelea spp. (larva) & Biting midge & $600(140)$ & 27 \\
\hline Bezzia spp. (larva) & Biting midge & $500(140)$ & 20 \\
\hline Cyclopoida & Cyclopoid copepod & $220(62)$ & 23 \\
\hline Haitia spp. & $\begin{array}{l}\text { Unidentified physid } \\
\text { snail }\end{array}$ & $120(29)$ & 17 \\
\hline Calanoida & Calanoid copepod & $120(55)$ & 17 \\
\hline Copepoda & Unidentified copepod & $100(28)$ & 16 \\
\hline Dryopidae (larva) & $\begin{array}{l}\text { Long-toed water } \\
\text { beetle }\end{array}$ & $90(44)$ & 5 \\
\hline Ephemeroptera (larva) & Mayfly & $70(24)$ & 14 \\
\hline Diptera (pupa) & Unidentified fly pupa & $60(14)$ & 20 \\
\hline Heteroptera & Aquatic bug & $40(12)$ & 13 \\
\hline Diptera (larva) & Unidentified fly & $43(9.9)$ & 16 \\
\hline Trichoptera (larva) & Caddis fly & $40(18)$ & 13 \\
\hline Ceratopogonidae (larva) & Biting midge & $40(21)$ & 9 \\
\hline Tipulidae (larva) & Crane fly & $21(10)$ & 6 \\
\hline
\end{tabular}




\begin{tabular}{|c|c|c|c|}
\hline Taxonomic group & Common name & $\begin{array}{l}\text { Mean density } \\
\left(\# \mathbf{m}^{-2}\right)(\mathrm{SE})\end{array}$ & $\begin{array}{l}\text { Number } \\
\text { of sites }\end{array}$ \\
\hline Stratiomyidae (larva) & Soldier fly & $19(9.4)$ & 7 \\
\hline Pelocoris femoratus & Alligator flea & $18(6.9)$ & 9 \\
\hline Collembola & Springtail & $16(7.4)$ & 7 \\
\hline Coenagrionidae (larva) & Damselfly & $15(5.5)$ & 11 \\
\hline Planorbella spp. & Planorbid snail & $15(8.6)$ & 8 \\
\hline Coleoptera (adult) & Aquatic beetle & $13(6.1)$ & 6 \\
\hline Berosus spp. (larva) & Aquatic beetle & $13(9.0)$ & 3 \\
\hline Gastropoda & Unidentified snail & $5(4.4)$ & 2 \\
\hline Enochrus spp. (larva) & Aquatic beetle & $4(2.7)$ & 3 \\
\hline Dolichopodidae (larva) & Long-legged fly & $3(3.4)$ & 1 \\
\hline Coleoptera (larva) & Aquatic beetle & $3(2.0)$ & 3 \\
\hline Littoridinops monroensis & Cockscomb hydrobe & $3(2.1)$ & 2 \\
\hline Anisoptera (larva) & $\begin{array}{l}\text { Unidentified } \\
\text { dragonfly }\end{array}$ & $2(1.9)$ & 2 \\
\hline $\begin{array}{l}\text { Erythemis simplicicollis } \\
\text { (larva) }\end{array}$ & $\begin{array}{l}\text { Eastern pondhawk } \\
\text { dragonfly }\end{array}$ & $0.7(0.69)$ & 1 \\
\hline Palaemonetes paludosus & Grass shrimp & $0.4(0.40)$ & 1 \\
\hline $\begin{array}{l}\text { Brachymesia gravida } \\
\text { (larva) }\end{array}$ & $\begin{array}{l}\text { Four-spotted pennant } \\
\text { dragonfly }\end{array}$ & $0.1(0.12)$ & 1 \\
\hline
\end{tabular}




\section{Supporting Information, Appendix S2}

\section{Candidate Models}

$4 \quad$ Model Development

5 We developed seven a priori structural equation models based on previous studies

6 and theoretical expectations. All models contained: 1) variables representing time since

7 flooding, periphyton total phosphorus, periphyton biomass (ash-free dry mass), the

8 combined relative abundance of diatoms and green algae, infauna density (from

9 periphyton core samples), herbivore density (from throw-trap samples), and omnivore

10 density (from throw-trap samples); 2) a covariance between time since flooding and

11 periphyton phosphorus; 3 ) direct effects of time since flooding on all variables except

12 periphyton phosphorus; and 4) direct effects of periphyton phosphorus on periphyton

13 biomass and the combined relative abundance of diatoms and green algae. Direct effects

14 of phosphorus enrichment on periphyton biomass and algal community structure have

15 been demonstrated previously (e.g., McCormick et al., 1996; Gaiser et al., 2005, 2006).

16 Hydrological impacts on consumer densities, periphyton biomass, and algal community

17 structure have been suggested by several studies (e.g., Trexler, Loftus, \& Perry, 2005;

18 Gottlieb, Richards, \& Gaiser, 2006; Liston, 2006). Thus, these elements were included in

19 all structural equation models. Models varied in their effects of variables representing

20 infaunal density, herbivore density, and omnivore density, based on models of food webs

21 and trophic interactions (e.g., Power, 1992). Models 1-4 included bottom-up effects (e.g.,

22 effect of infauna density on omnivore density) only, and differed in their inclusion of

23 omnivory (direct effect of periphyton biomass on omnivore density) and effects of 
24 herbivores on omnivores. Models 5-7 included both bottom up effects and reciprocal

25 top-down effects (e.g., effect of omnivore density on infauna density), and also differed

26 in their inclusion of omnivory and relationships between herbivores and omnivores. We

27 were unable to test models containing reciprocal relationships between omnivore density

28 and herbivore density due to empirical underidentification.

29

$30 \quad$ Model 1: Bottom-up control, omnivory present

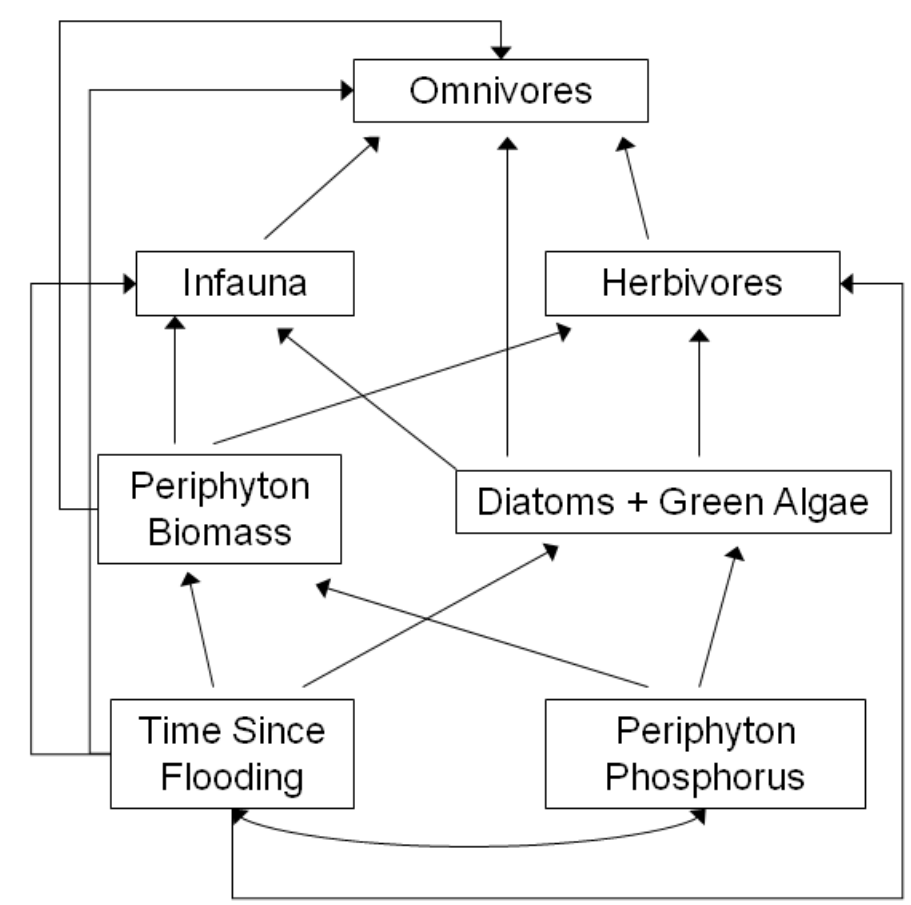

31 
38 Model 2: Bottom-up control, omnivory absent

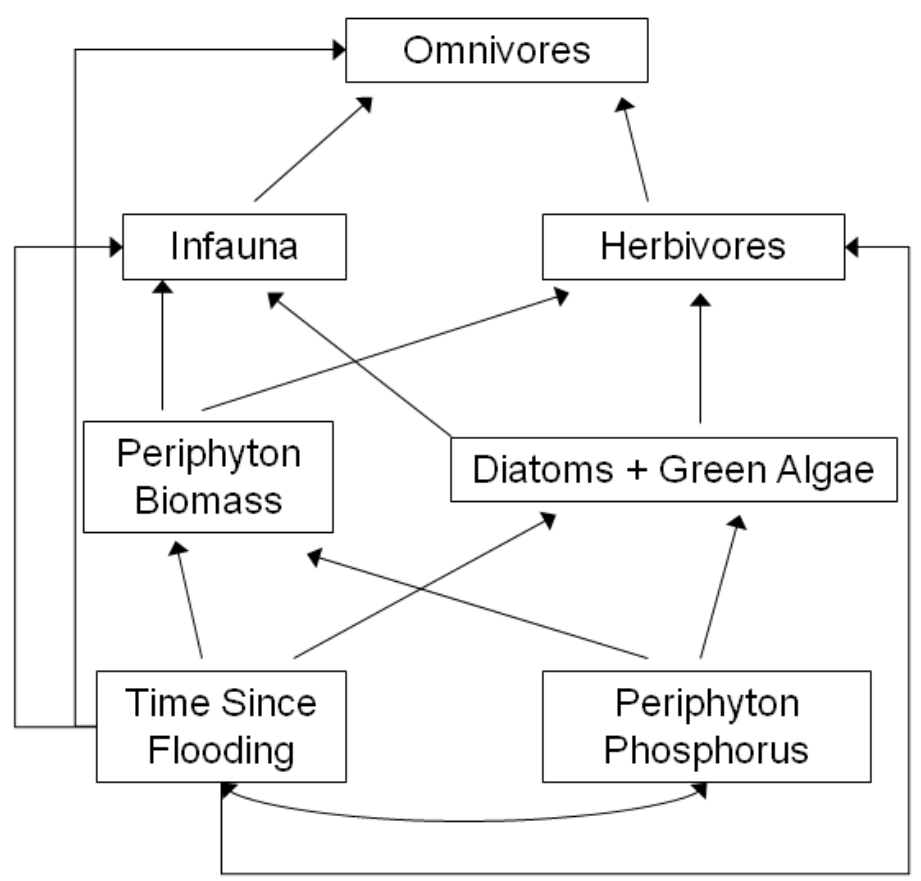

39

40 Model 3: Bottom-up control, omnivory absent, no path between herbivores and

41 omnivores

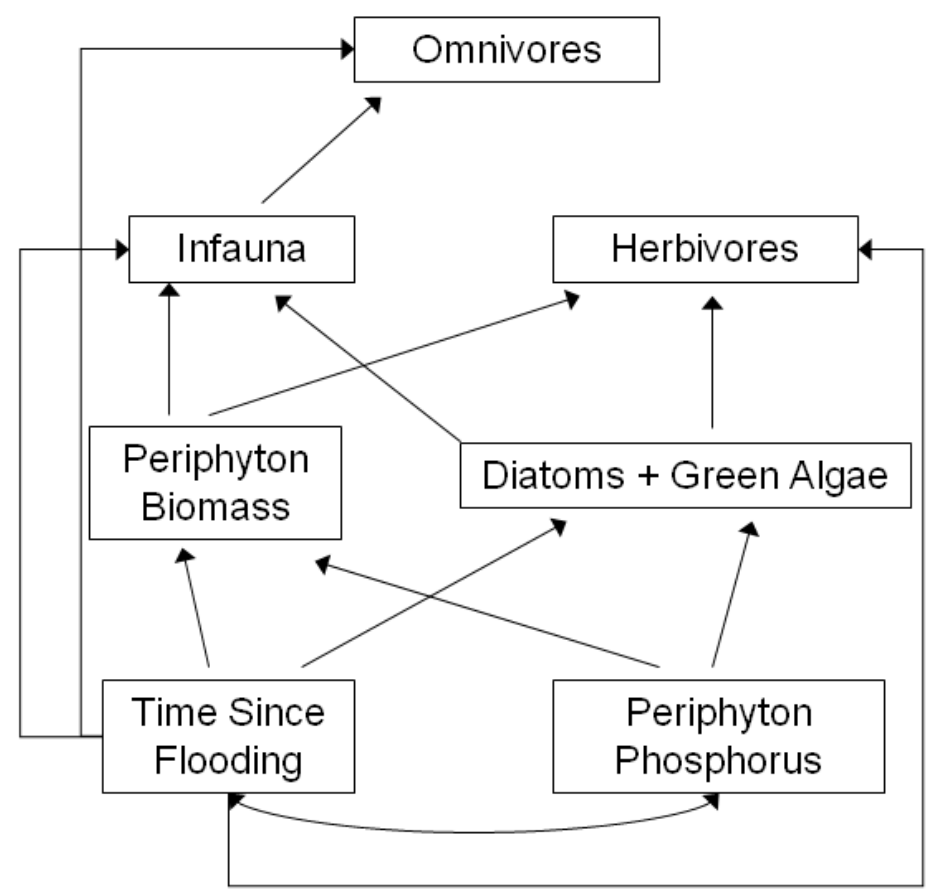

42 
43 Model 4: Bottom-up control, omnivory present, no path between herbivores and

44 omnivores

45

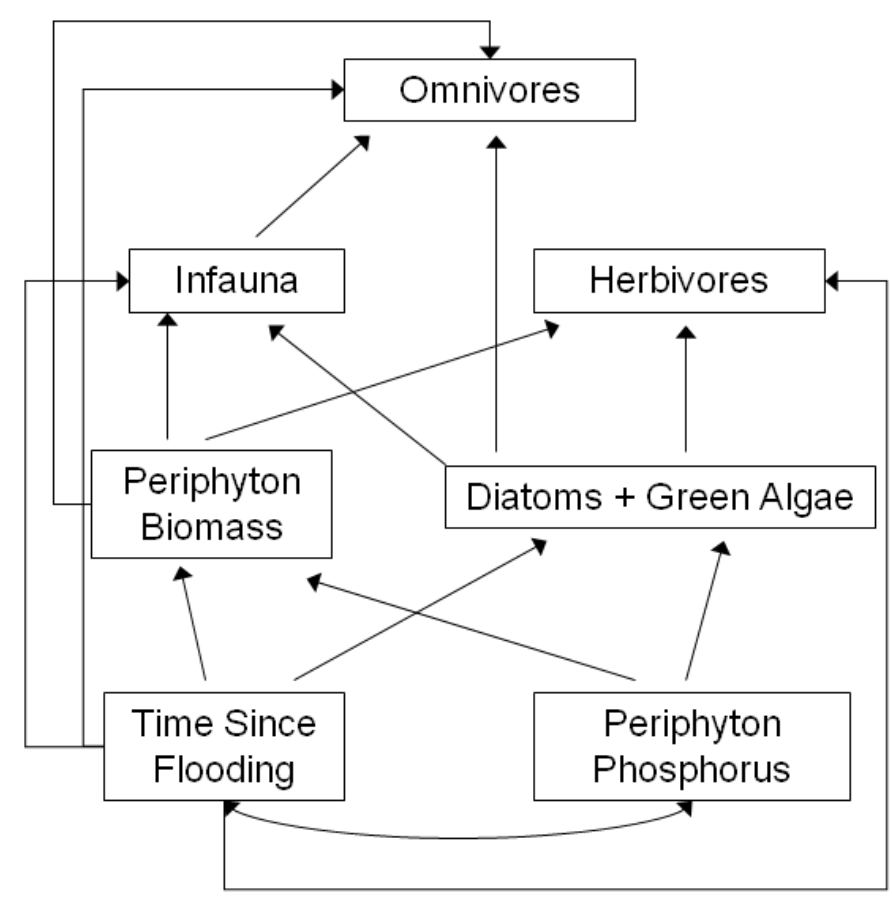

46 Model 5: Bottom-up and top-down control, omnivory absent, no path between herbivores

47 and omnivores

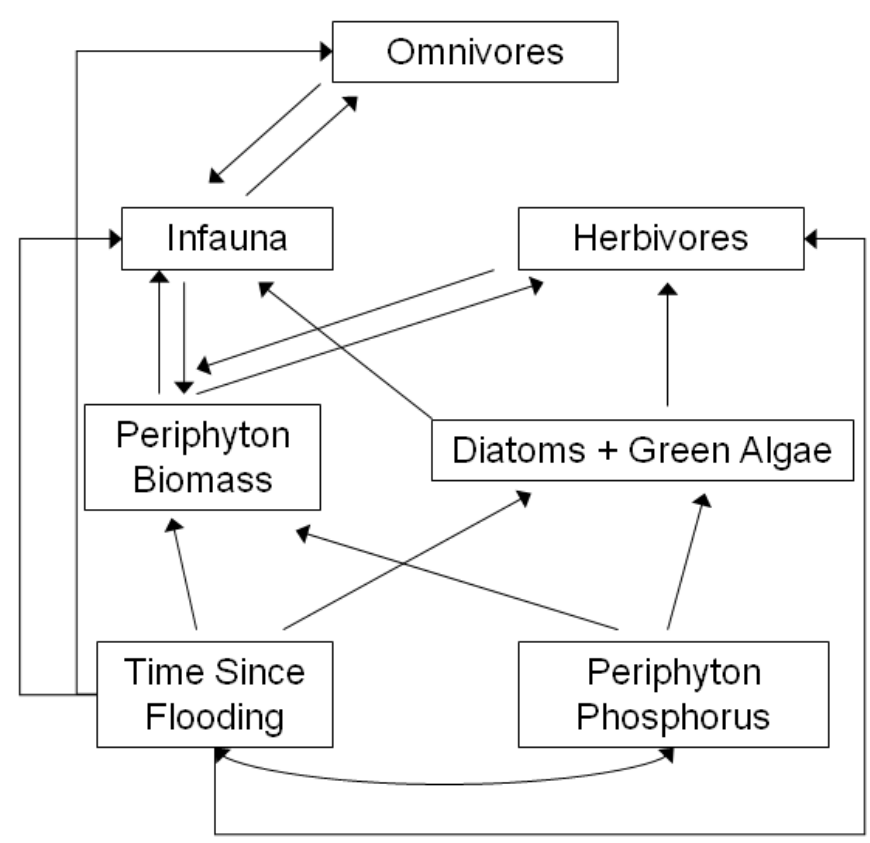

48

Freshwater Biology 
49 Model 6: Bottom-up and top-down control, omnivory absent, only bottom-up control

50 between herbivores and omnivores

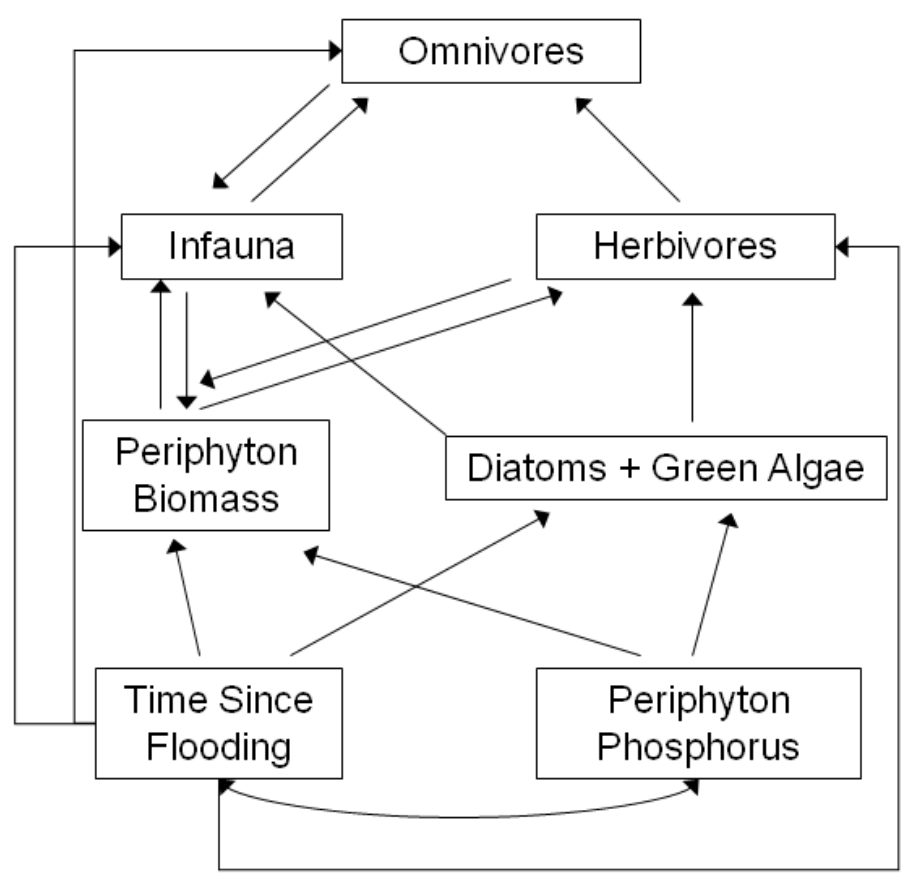

51

52 Model 7: Bottom-up and top-down control, omnivory present, only bottom-up control

53 between herbivores and omnivores

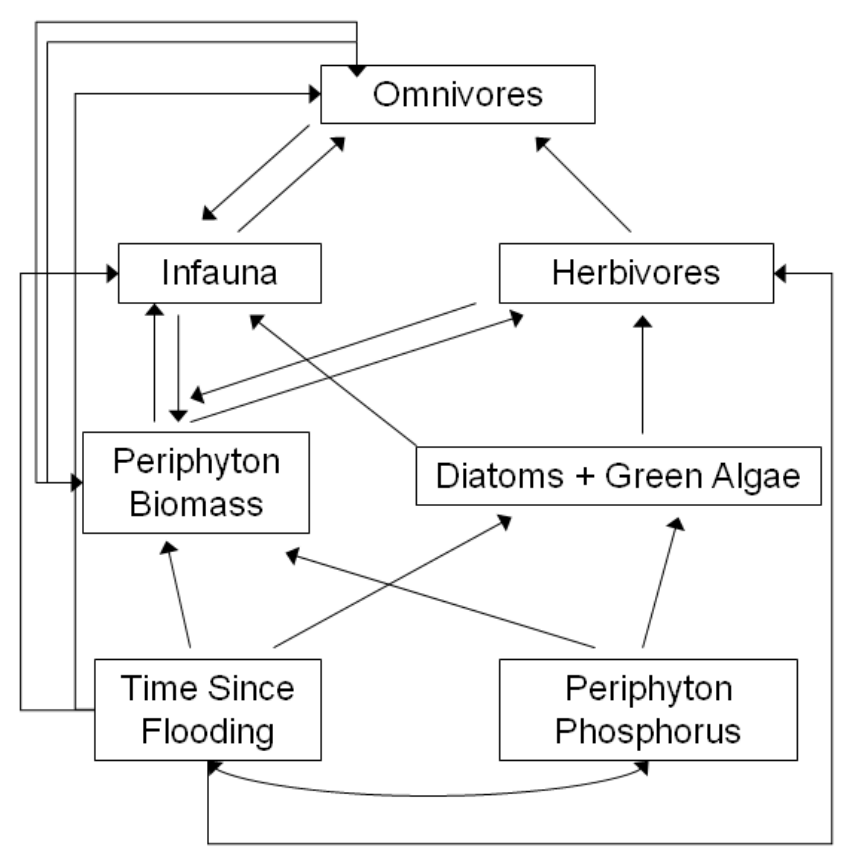

54

Freshwater Biology 
56 References

57 Gaiser E.E., Childers D.L., Jones R.D., Richards J.H., Scinto L.J., \& Trexler J.C. (2006)

58 Periphyton responses to eutrophication in the Florida Everglades: Cross-system

59 patterns of structural and compositional change. Limnology and Oceanography,

60 51, 617-630. doi: 10.4319/lo.2006.51.1_part_2.0617

61 Gaiser E.E., Trexler J.C., Richards J.H., Childers D.L., Lee D., Edwards A.L., Scinto

L.J., Jayachandran K., Noe G.B., \& Jones R.D. (2005) Cascading ecological effects of low-level phosphorus enrichment in the Florida Everglades. Journal of Environmental Quality, 34, 717-723. doi:10.2134/jeq2005.0717

65 Gottlieb A.D., Richards J.H., \& Gaiser E.E. (2006) Comparative study of periphyton 66 community structure in long and short-hydroperiod Everglades marshes.

68 Liston S.E. (2006) Interactions between nutrient availability and hydroperiod shape macroinvertebrate communities in Florida Everglades marshes. Hydrobiologia, 569, 343-357. doi: 10.1007/s10750-006-0141-0

71 McCormick P.V., Rawlik P.S., Lurding K., Smith E.P., \& Sklar F.H. (1996) Periphytonwater quality relationships along a nutrient gradient in the northern Florida Everglades. Journal of the North American Benthological Society, 15, 433-449.

74 Power M.E. (1992) Do plants have primacy? Ecology, 73, 733-746. doi: 
76 Trexler J.C., Loftus W.F., \& Perry S. (2005) Disturbance frequency and community

77 structure in a twenty-five year intervention study. Oecologia, 145, 140-152. doi:

$78 \quad 10.1007 / \mathrm{s} 00442-005-0094-4$ 